\section{Gramática de la casa. Perspectivas de análisis arqueológico de los espacios domésticos medievales en la península Ibérica (siglos VII-XIII)}

\section{A Grammar of the house. Perspectives of archaeological analysis in medieval domestic spaces in the Iberian Peninsula $\left(7^{\text {th }}-13^{\text {th }}\right.$ centuries)}

\section{Sonia Gutiérrez Lloret*}

Universidad de Alicante

\section{Resumen}

El espacio doméstico construido es un producto social que a su vez crea sociedad. La casa constituye un escenario privilegiado, un medio de expresión y transmisión de conductas y comportamientos. No obstante, resulta muy difícil comprender el espacio social a través de unas ruinas arqueológicas vacías y carentes de tercera dimensión, y se corre el riesgo de proyectar una imagen historiográfica previamente construida sobre las sociedades estudiadas. La comprensión del espacio social requiere formalizar y discutir los patrones formales de las estructuras domésticas y sus formas de agrupación.

Este trabajo aborda el estudio de los espacios domésticos desde una perspectiva lingüística (una gramática de la casa), distinguiendo los elementos en sí y sus combinaciones. Se definen tres niveles distintos de análisis del hecho doméstico: el morfológico, que se ocupa de la forma de las unidades domésticas y de las transformaciones que experimentan; el sintáctico que enfatiza las relaciones entre las estructuras elementales en el marco de una estructura espacial organizada; y el semiótico, que las analiza como expresiones sociales, materialización e instrumento de significados culturales. De acuerdo a esta perspectiva se propone una reflexión metodológica sobre la caracterización de los espacios domésticos medievales e islámicos en la Península Ibérica; se plantean los problemas derivados de uso social del espacio, los modelos domésticos y su diacronía, y se discute acerca de la casa como indicador material de islamización.

Palabras clave: Arqueología de los espacios domésticos, Morfología, sintaxis, semiótica, modelos domésticos, entorno construido, tramas urbanas, uso social del espacio, casa islámica, Arqueología medieval, Península Ibérica, al-Andalus.

\section{Abstract}

The constructed domestic space is a social product which, at the same time, creates society. The house constitutes a privileged scenario, a way of expression and transmission of behaviours. Nevertheless, it seems very difficult to understand the social space through some archaeological ruins, empty and lacking of third dimension, so the risk to cast a historiographica image previously made over the studied societies is high. The understanding of the social space demands to formalize and discuss the formal patterns of the domestic structures and their grouping forms.

This paper deals with the study of the domestic spaces from a linguistic perspective (a grammar of the house), distinguishing the elements into themselves and their combinations. Three different levels of analysis of the domestic fact are defined: the morphological, which tackles the form of the domestic units and the transformations they suffer; the syntactic, which emphasizes the relations between the elemental structures in the framework of an organized spatial structure; and the semiotic, which analyzes them as social expressions, materialization and instrument of cultural meanings. In agreement with this perspective, a methodological reflection is suggested about the characterization of the medieval and Islamic domestic spaces in the Iberian Peninsula; the problems that come from the social use of the space is set out, the domestic patterns and their diachronic, and it is discussed about the house as an Islamization material marker.

Key words: Household Archaeology, Morphology, Syntax, Semiotics, Domestics models, Built environment, Urban pattern, Social use of space, Islamic house, Medieval Archaeology, Iberian Peninsula, al-Andalus.

* Sonia.gutierrez@ua.es.

1 Este trabajo se ha realizado en el marco del proyecto de investigación HAR2009-11441 (Lectura arqueológica del uso social del espacio. Análisis transver-
Desde el final de la tarde prendieron una fogata enorme en el centro de la casa. Uno de esos patios que tienen las casas de cuatro lados, para abrir sobre ellos balcones y barandales ávidos de luz y temerosos del campo abierto

Ángeles Mastretta, Mujeres de ojos grandes, 1990

\section{¿POR QUÉ UNA GRAMÁTICA DE LA CASA?}

La casa como «edificio para habitar», pero también como espacio de la familia ${ }^{2}$, constituye un escenario social privilegiado. El espacio doméstico construido es un producto social que a su vez crea sociedad, en tanto que actúa como medio de expresión y transmisión de conductas y comportamientos ${ }^{3}$. La lectura social del espacio doméstico construido, de su lógica formal y organizativa, entraña el análisis complejo de su configuración, articulación interna, emplazamiento, visibilidad y visibilización, pero también trasciende esta dimensión puramente constitutiva del entorno construido, para englobar la actividad doméstica que en él se desarrolla, en tanto que unidad básica de producción y reproducción social.

Al hablar de la casa en sociedades históricas se plantean varios problemas, que van desde la ambigüedad conceptual que reflejan las distintas semánticas empleadas para designarla, al dificultoso reconocimiento de su significado social a partir de los testimonios contemporáneos y los vestigios materiales que perduran. En ambos casos han atravesado el tiempo histórico con casuísticas y condicionantes tan variados y variables que no siempre son fácilmente contrastables o simplemente aprehensibles. La coexistencia de categorías como «unidad de edificación», «espacio habitacional», «unidad doméstica», «unidad habitacional», "grupo doméstico», "vivienda" o simplemente "casa» (según se connote la perspectiva morfológica, funcional, antropológica o social) a más de los referentes

sal de la protohistoria al Medioevo en el Mediterráneo Occidental) del MICINN. Quiero dejar constancia de mi gratitud a Víctor Cañavate, Débora Kiss, Ignacio Grau y Javier Jover, que además de ayudarme a formalizar gráficamente mi propuesta en los dos primeros casos, han discutido y matizado mi propia reflexión en un diálogo científico sumamente enriquecedor. Igualmente agradezco a Agustín Azkarate y José Luis Solaun, Patrice Cressier, James L. Boone, Lauro Olmo, Valeria Beolchini, Alberto Lorrio, Juan Antonio Quirós, Rafael Azuar, Manuel Acién, Fernando Prados, José Ramón García Gandía y Antonio Vallejo que me hayan facilitado trabajos, datos, comentarios, sugerencias o materiales gráficos inéditos para elaborar este trabajo. Por fin, mi reconocimiento al equipo científico del proyecto HAR2009-11441 y a los participantes en el International Workshop From domestic structure to social life. Archaeological readings of social use of space, por discutir y en consecuencia enriquecer estos argumentos.

${ }^{2}$ Los sentidos que da el Diccionario de la lengua Española (RAE) en su $1^{\mathrm{a}}$ y $5^{\mathrm{a}}$ acepción, y los mismos que tiene el término (A $\underline{k h k h a m)}$ que designa la maison Kabyle (Missoum 1995: 126).

${ }^{3}$ Quizá la más modélica de las estructuras estructuradas que funcionan como estructuras estructurantes, en conocida expresión de P. Bourdieu (1972: 175 ss). 
históricos medievales, documentados en las fuentes o «resignificados» por la historiografía moderna a partir de los términos árabes, latinos o romances que los designan en el Medievo ${ }^{4}$, son una buena prueba de la complejidad conceptual antedicha.

Y si hablamos desde la arqueología, a esta complejidad se le suma la dificultad intrínseca de aprehender los significados sociales y simbólicos del espacio doméstico, al modo antropológico de Pierre Bourdieu en el caso de la casa de la Kabylia ${ }^{5}$, desde la materialidad de ruinas vacías de objetos e interlocutores: a significance which could never be deduced from the empty or ruined remains of the house itselff (Fentress 2000: 20).

A la hora de estudiar los espacios domésticos hay que distinguir, como si de una gramática se tratase, los elementos en sí y sus combinaciones. De esta forma se definen tres niveles distintos de análisis del hecho doméstico: el morfológico, que se ocupa de la forma de las unidades domésticas $\mathrm{y}$ de las modificaciones o transformaciones que experimentan, y que suele ser el más comunmente transitado por orientaciones funcionalistas y taxonómicas que presiden frecuentemente los diversos ámbitos históricos de estudio; el sintáctico que enfatiza las relaciones entre las estructuras elementales y, al modo del lenguaje, las percibe en el marco de una estructura espacial organizada más comple$\mathrm{ja}^{6}$. Y, por fin, la dimensión semiótica, que las analiza como expresiones sociales, materialización e instrumento de significados culturales, y se centra en el uso social del entorno construido, es decir, en las relaciones entre los espacios construidos y la estructura social que los concibe y ejecuta a través de expresiones arquitectónicas concretas ${ }^{7}$.

Creo que en ocasiones se confunden los tres niveles de lectura y de esta forma, descriptores puramente morfológicos se transforman, sin que se expliciten convenientemente los argumentos, en modelos sociales. Se interpretan signifi-

\footnotetext{
${ }^{4}$ Por ejemplo, Bayt y Dār en árabe, con todas sus matizaciones temporales y geográficas (Missoum 2010: 150); términos latinos como los de domus solarate o domus terrinee utilizados en el altomedioevo romano para designar las residencias urbanas de la aristocracia o del común de la población (Santangeli Valenzani 2011: 91 ss); o los términos cases, siempre en plural para referirse a una unidad doméstica en contextos de colonización feudal (Torró 1992: 175); o alberch para designar unidades domésticas completas con patio y crujías en las alquerías moriscas valencianas (Torró 2009: 207-8).

${ }^{5}$ La maison ou le mond renversé (Bourdieu 1972: 45-69).

${ }^{6}$ Y que debe mucho a la aplicación cada vez más extendida de herramientas y metodologías de análisis espacial (análisis sintácticos o perceptivos del espacio, a más de las aproximaciones basadas en herramientas arqueológicas clásicas como los análisis estratigráficos, cronotipológicos, de la estructura formal, etc), que permitieran reconocer la lógica estructural más allá de la casuística concreta, mediante planteamientos propios de la Arqueotectura, la Household Archaeology o las Arqueologías de la Arquitectura, de la Producción y de la Construcción.

${ }^{7}$ Sobre la aproximación lingüística y la perspectiva estructuralista en el estudio del registro arqueológico F. Criado (2012, en particular 227ss).
}

cantes formales sin comprender que sus significados dependen de una metodología acurada, capaz de reconocer e identificar áreas de actividad y secuencias estratigráficas complejas. Se descontextualizan y diluyen las unidades de análisis básicas (los signos, siguiendo el paradigma lingüístico) sin imbricarlos en su sintaxis, esto es, «sin contextualizarlos en una red de imbricaciones» (Bermejo 2009: 49), que en Arqueología no significa otra cosa que disponer de excavaciones en extensión, metodológicamente rigurosas, que permitan analizar las tramas y relaciones espaciales. $\mathrm{O}$ bien simplemente se planea sobre visiones sesgadas del conjunto (a menudo basadas en plantas de elementos múltiples, que representan la totalidad de las estructuras relevantes con independencia de su cronología, en lugar de plantas compuestas de fase con áreas de actividad identificadas) y que, en consecuencia, no recogen superficies sincrónicas significativas e impiden apreciar de manera diacrónica los cambios en la organización y uso del espacio, reforzando una imagen estática de los espacios domésticos que termina por caracterizar antropológicamente las sociedades estudiadas.

La lectura arqueológica del uso social del espacio, ya de por si compleja desde la materialidad de ruinas vacías y carentes de alzados (la tercera dimensión que define el espacio per se), resulta imposible sin estos requisitos previos y a menudo se convierte en un reconocimiento aparente de significados sociales proyectados desde una imagen historiográfica previamente construida sobre las sociedades que se estudian. En este sentido, la experiencia multidisciplinar y multidimensional de lectura transversal de espacios sociales distintos, aplicando idénticas herramientas y metodologías de análisis espacial ${ }^{8}$, ha permitido reconocer patrones de racionalidad comunes o al menos comparables, entre sociedades muy alejadas en tiempo y características (Criado y Mañana, 2003: 105), como parecía intuirse en ciertas configuraciones de los entornos construidos protohistóricos y altomedievales, en los contextos de cambio y ruptura impuestos por procesos de transformación social como la romanización y la islamización.

La cuestión era, obviamente, determinar si esta similitud morfológica y funcional podía implicar significantes simbólicos y sociales comunes, cosa que no parece probable, pero que al mismo tiempo evidencia claramente los límites y riesgos de una lectura social (de una inferencia semiótica) directa o de trazo grueso, a partir de la semejanza de expresiones arquitectónicas concretas. Está por ver, por acudir un ejemplo preciso, si ciertos marcadores de

\footnotetext{
${ }^{8}$ Proyecto de investigación HAR2009-11441, vid. supra n. 1.
} 


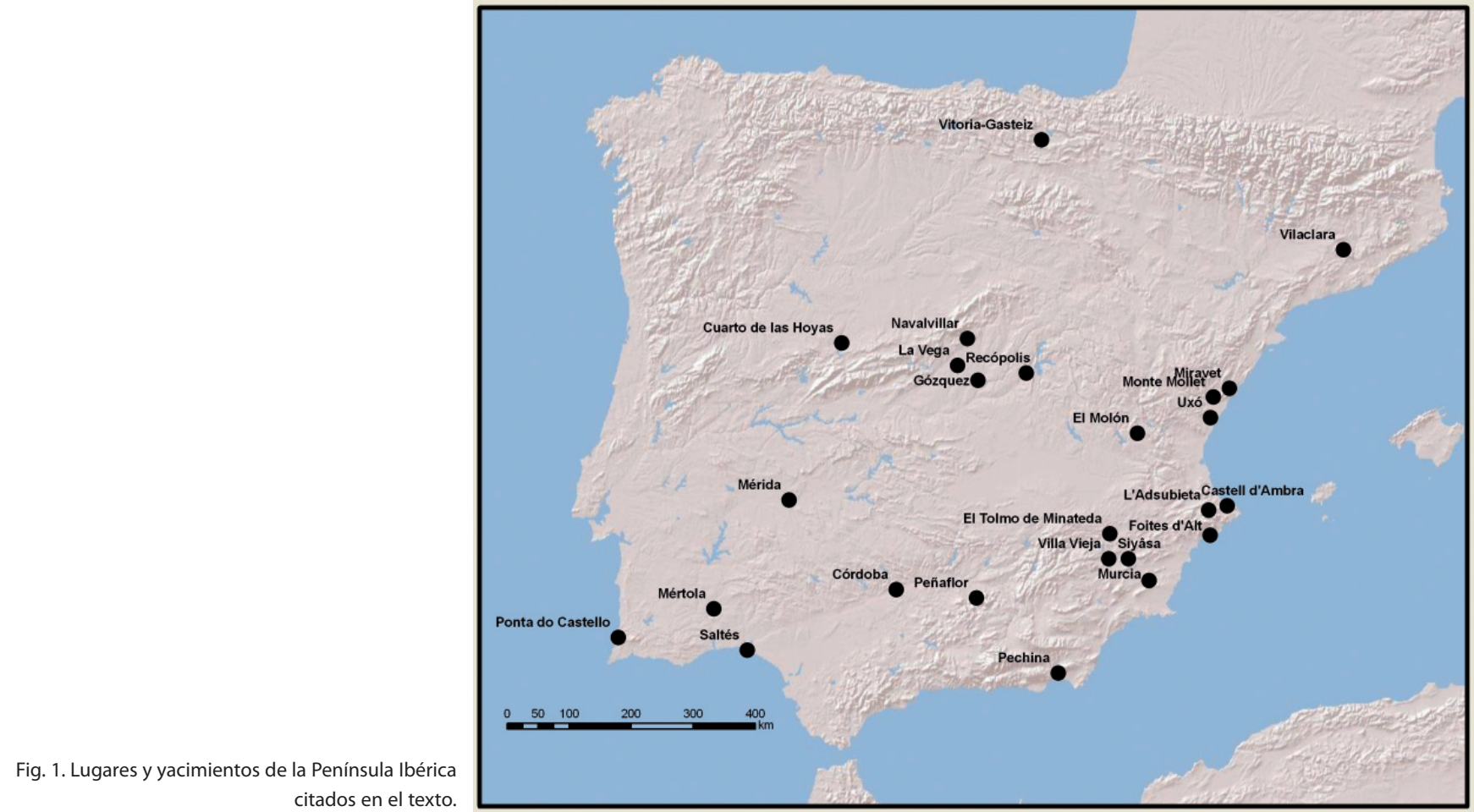

privacidad y preservación de la intimidad en las plantas domésticas púnicas (Fantar 1985) e islámicas en la Antigüedad y en el Medievo respectivamente, significan socialmente lo mismo respecto al control de las mujeres y la hegemonía de lo privado, por más que ambas hurten la percepción y accesibilidad al núcleo central de la vivienda, el patio, mediante un recurso arquitectónico en principio comparable: el acceso lateral mediante un corredor en codo. La morfología e incluso la sintaxis de la gramática de la casa son a menudo comparables en expresiones arquitectónicas concretas, pero su significado social puede no ser el mismo. No conviene olvidar, como ya advirtieron los lingüistas, que la relación entre significante y significado es siempre arbitraria y la asignación de significados a los significantes materiales requiere de procedimientos de contrastación arqueológica metodológicamente depurados, sin los cuales la interpretación del uso social del espacio será siempre un gigante construido sobre los pies de papel de modelos definidos a partir de la bidimensionalidad congelada de una "planta» arqueológica.

Este trabajo pretende trazar una reflexión metodológica sobre los espacios domésticos medievales. No debe el lector buscar aquí un análisis teórico de la arqueología de los espacios domésticos o de la teoría de la sintaxis espacial, en la línea de la Household Archaeology, de la Arqueología de la Arquitectura o del Paisaje, ni tan siquiera un balance o comentario sobre las estrategias metodológicas e interpre- tativas aplicadas en la comprensión social del espacio doméstico ${ }^{9}$. No lo encontrará, como tampoco hallará un análisis diacrónico de manifestaciones arquitectónicas, unidades constructivas o configuraciones espaciales concretas y su evolución en el Medievo, excepción hecha de alguna ejemplificación puntual. Ésta es, consciente y voluntariamente, una reflexión metodológica, destinada a discutir patrones formales de estructuras domésticas y formas de agrupación de las mismas (esto es, de morfologías y sintaxis), que se centra inicialmente en la caracterización del espacio ${ }^{10}$. La diacronía en tanto que transformación es un argumento fundamental, pero en un primer nivel de análisis la comprensión del espacio puede ser independiente de la percepción de sus tiempos, o al menos en nuestro planteamiento viene después. Obviamente se ha

\footnotetext{
9a bibliografía es extensa y variada; sin ánimo de exhaustividad algunas referencias clásicas desde la arqueología doméstica (Netting, Wilk \& Arnould, 1984; Manzanilla 1986; Allison 1999; Nevett 1999); el espacio social y la arquitectura (Hillier \& Hanson 1984; Rapoport 1972, 1978; Kent 1990; Miller Lane 2007); la antropología y la semiótica (Bourdieu 1972; Eco 1986; Steadman 1996; Criado 1999) o la arqueología social (Zarankin y Acuto 1999; Acuto y Zarankin 2008; Adánez Pavón 2003; Fernández Souza, L., 2010). Planteamientos y síntesis generales en Bermejo Tirado 2009, Azkarate 2010 y e. p., Ayan et alii 2003 , Taboada y Angiorama 2003, Adánez 2003, Vaquer 2007 y Kiss e. p., entre otras

${ }^{10}$ La dimensión semiótica de la casa en el contexto histórico que nos ocupa y la discusión de los modelos sociales de la misma, excedería el marco y el espacio de este trabajo, por lo que sólo se plantean algunas cuestiones que se desarrollarán en otro lugar (Gutiérrez Lloret e.p.).
} 
acotado un marco cronológico amplio para esta reflexión, que comprende el análisis de las particulares expresiones arquitectónicas (espacios domésticos y entornos construidos) y sociales correspondientes al final de la Antigüedad y a la formación del Medievo en la Península Ibérica. Esto supone desde el punto de vista histórico la desaparición de los modelos residenciales aristocráticos rurales y urbanos propios de la Antigüedad, la aparición de nuevas formas de asentamiento altomedieval eminentemente rural, la creación de formas de poblamiento urbano y rural que llevan aparejada la introducción y generalización de nuevos modelos domésticos de origen mediterráneo y nuevos paisajes sociales, legibles, creemos, en la transformación de los entornos construidos a partir de los siglos VIII y IX, en el marco de un proceso de cambio y ruptura tan significativo como la islamización de al-Andalus.

La desestructuración de las formas de ocupación del territorio y de organización del espacio en el final de la Antigüedad, con la desaparición de las uillae en tanto que centros productivos rurales de organización jerárquica y lugares de representación aristocrática en el medio rural (Chavarria, 2007; Vigil-Escalera, 2009), así como la crisis de la ciudad antigua (Brogiolo, 2011) suponen importantes procesos de mutación de los entornos construidos, sean rurales o urbanos, perfectamente legibles en el registro arqueológico, en las transformaciones de los diseños formales, su segmentación, cambio de uso, abandono, etc. De la misma forma, la aculturación y el nuevo conjunto de relaciones sociales que implica el proceso de islamización, debería estar acompañado por la transformación del entorno construido, en cuyo marco la generalización de una nueva tipología de vivienda «islámica» denota las nuevas relaciones sociales y familiares (Fentress 2000). No obstante, más allá del marco cronológico acotado, se ha evitado conscientemente elegir el eje temporal para ordenar los espacios domésticos y proponer su evolución; por el contrario se pretende primero definir los espacios $y$, en todo caso, secuenciarlos y connotarlos socialmente después.

En cierto modo, parafraseando la reflexión de Gianni Rodari en su Grammatica della fantasia (título al que se refiere el de este trabajo), mi reflexión no es ni una teoría del espacio doméstico (en la línea de la Arqueología de la Arquitectura), ni una colección de recetas (una metodología de análisis arqueotectónico), ni un manual de historias (explicación diacrónica de las casas y sus procesos formativos en las distintas sociedades), sino una propuesta de reflexión sobre el análisis arqueológico del uso social de los espacios domésticos medievales, que permita reconocer y comprender los significativos procesos sociales que convulsionan la Alta Edad Media ${ }^{11}$.

\section{LA MORFOLOGÍA: ¿PARA QUÉ LOS MODELOS?}

La taxonomía constituye un instrumento descriptivo que permite la ordenación jerarquizada y sistemática de las unidades domésticas según su morfología. La clasificación es, en consecuencia, un mecanismo de comprensión del hecho doméstico, que describe y explica de forma paralela las modificaciones o transformaciones que experimentan dichas estructuras. Si descendemos al detalle de la casuística concreta, las clasificaciones de las viviendas medievales son aparentemente variadas y adaptadas a la idiosincrasia específica de cada asentamiento ${ }^{12}$. Sin embargo, una visión más amplia pone en evidencia que en la práctica se suele trabajar con dos categorías básicas (casi podríamos decir universales puesto que se adoptan por igual en varios contextos históricos y geográficos; Belarte 2009, Manzanilla 1986), que definen por regla general dos modelos domésticos: la casa sencilla, elemental o monocelular, formada por una única estancia, y la casa compleja o pluricelular, compuesta por varias estancias articuladas entre sí. En fondo y forma, ambas constituyen los dos modelos fundamentales de clasificación de la unidad doméstica, a los que se suelen aplicar significados sociales más o menos explícitos, en relación con la estructura familiar, las referencias culturales o incluso la etnicidad (Fentress 2000, Boone 2001, Santangeli Valenzani 2011: 67 ss.).

Resulta interesante observar cómo ambas categorías se repiten con independencia de la realidad histórica y social que representan y se encuentran por igual en sociedades visigodas, islámicas y feudales, por poner ejemplos que afectan directamente a nuestro ámbito de estudio ${ }^{13}$. Así,

\footnotetext{
${ }^{11}$ Gianni Rodari, Grammatica della fantasia. Introduzione all'arte di inventare storie, 1973, Piccola biblioteca Enaudi (Gramática de la fantasía: Introducción al arte de contar historias, Barcelona, Planeta, 2009). La cita libremente parafraseada procede del capítulo "Imaginación, creatividad, escuela» y dice así: "La presente gramática de la fantasía [...] no es ni una teoría de la imaginación infantil (faltaría más...), ni una colección de recetas, ni un manual de historias sino, pienso, una propuesta más entre todas las otras que tienden a enriquecer con estimulos el ambiente (casa o escuela, da lo mismo) en que el niño crece».

${ }^{12}$ Véase por ejemplo la clasificación cordobesa para las viviendas califales del arrabal de poniente (Cánovas et alii 2008 y Murillo et alii, 2010), la de las viviendas almohades de La Villa Vieja de Calasparra, entre otros muchos (Pozo et alii 2002: 164) o la de casas urbanas bajomedievales de Toledo (Passini 2004)

13 Pero también está presente en sociedades prehispánicas mexicanas, donde M. Winter identificó, a propósito de Oaxaca, unidades domésticas abiertas de una sola estructura residencial, semicerradas con dos estructuras separadas delimitando un patio central y cerradas en torno a un patio en una tipificación que relaciona complejidad estructural con rango social (Winter 1986: 337-30); o en sociedades protohistóricas mediterráneas, como las iberas, donde se señala la coexistencia de un modelo de casa sencilla y otra compleja (Belarte et alii 2009: 111), al tiempo que se enfatiza el significado social de esta variabilidad (Sala y
} 


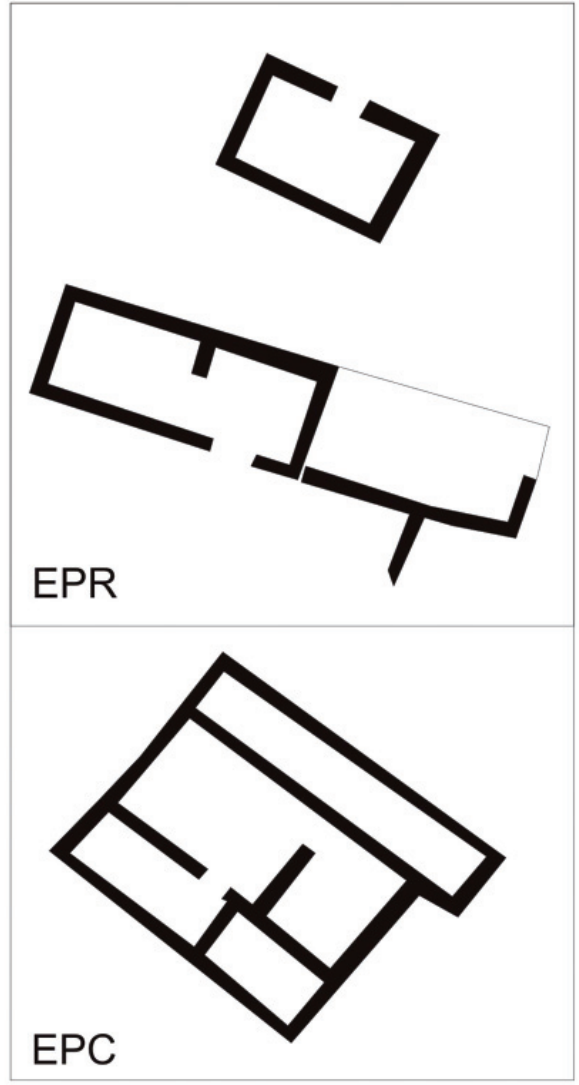

1

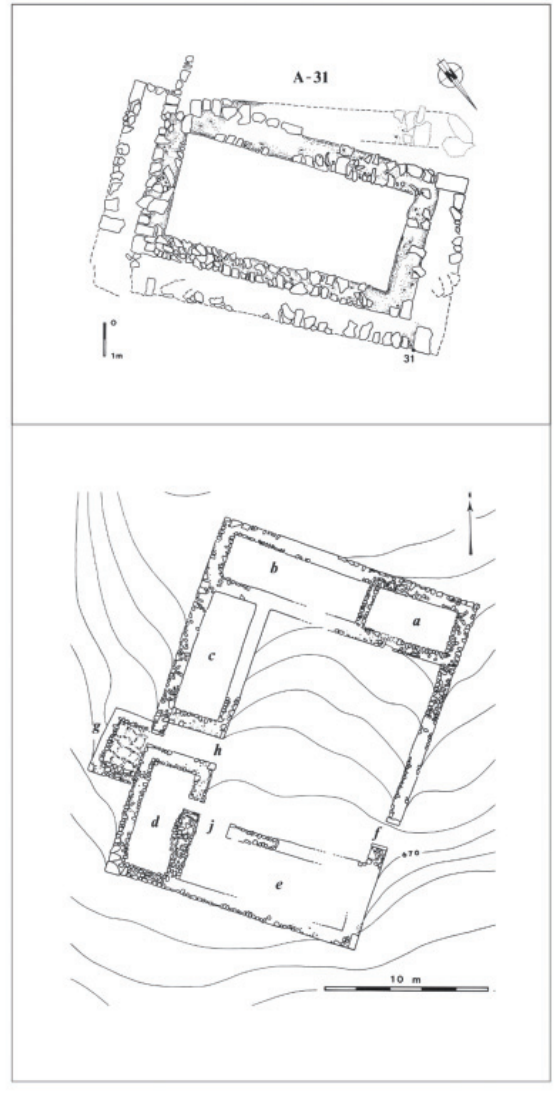

2

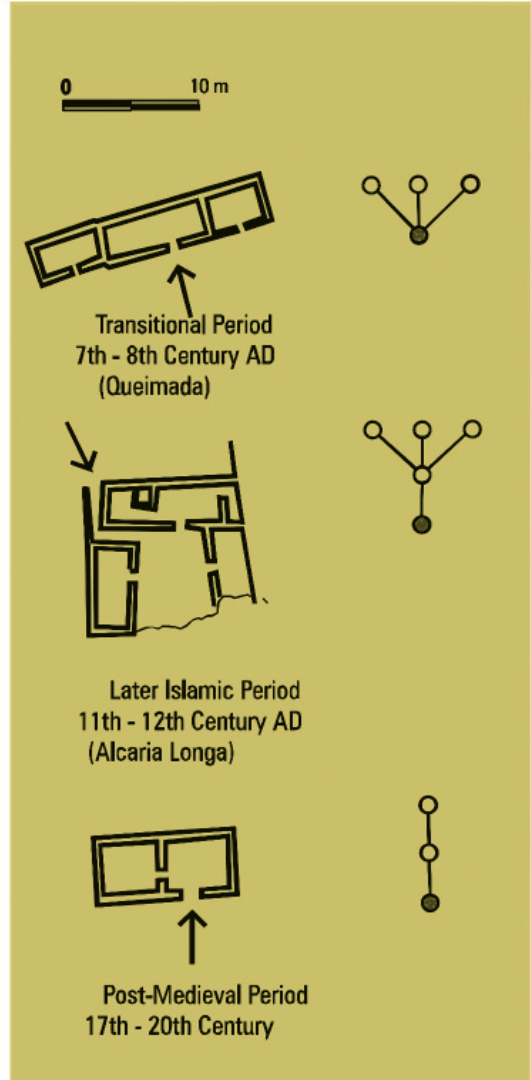

3

Fig. 2. Comparación de modelos domésticos: 1. Unidad de edificación de planta rectangular (EPR) y unidad de edificación de planta compleja (EPC) (según Vigil-Escalera 2003: 288, fig. 1); 2. Maison monocellulaire y pluricellulaire (según Bazzana 1992: 164 ss, Guichard y Van Staëvel 1995: fig. 48); 3. Evolución de la casa rural en el Baixo Alentejo (según Boone 2001: fig. 7)

Alfonso Vigil-Escalera (2003: 288) ha planteado la coexistencia regular de ambos modelos domésticos en diferentes yacimientos altomedievales en la Meseta (Madrid y Toledo) fechados de principios del siglo VI a mediados del VIII: de un lado, la unidad de edificación de planta rectangular (EPR), a veces con división interna y con frecuente recurso a la yuxtaposición; de otro, la unidad de edificación de planta compleja (EPC) con tres o cuatro ambientes diferenciados (uno alargado y estrecho cerrando generalmente uno de los lados) y una posible especialización funcional de los mismos ${ }^{14}$ (Fig. 2.1).

Por otro lado, el estudio ya clásico de la casa islámica en al-Andalus realizado por André Bazzana, plantea igual-

Abad 2006: 40-41;). Los términos sencillo y complejo plantean una indefinición conceptual, derivada de su enfoque cualitativo, que los hace ambiguos y no necesariamente sinónimos de unicelular o pluricelular, conceptos morfológicamente más precisos. Es el caso de J. Navarro Palazón (1990) que define dos modelos de viviendas en Siyâsa: el tipo elemental y el complejo, según el número de crujías, si bien en rigor ambos son pluricelulares en tanto que presentan varios módulos.

${ }^{14}$ Esta modelización fue planteada a partir de ejemplos fundamentalmente rurales, que correspondían a las categorizaciones arqueológicas de «asentamiento disperso" y «agregado» formuladas por el mismo autor (Vigil-Escalera 2006 a). mente la existencia de una maison monocellulair, la casa rectangular simple sin ventanas, cuyo origen vincula a la taddart bereber marroquí sin descartar influencias ibéricas indígenas en algunas regiones, frente a la maison pluricellulaire compleja surgida de la yuxtaposición de células organizadas generalmente en torno a un patio, de acuerdo a las necesidades de vida comunitaria. Esta última es considerada un sistema de habitación universal o al menos mediterráneo, que anuncia el modelo de casa islámica caracterizada por la segregación funcional de los espacios domésticos (Bazzana 1992, 164-175). Ambos tipos fueron ejemplificados a partir de las casas A-31 y U-71/72 de Monte Mollet en Castellón (siglos VII y IX), según interpretación gráfica realizada por Pierre Guichard y Jean Pierre Van Staëvel (1995: 46, fig. 8 a y b) (Fig. 2.2) ${ }^{15}$. Se trata en

\footnotetext{
15 En rigor André Bazzana ha reformulado recientemente su planteamiento tipológico, inspirándose en los trabajos de la Escuela Alemana de Arquitectura; en la actualidad considera que la maison médiéval n'est pas le résultat d'une juxtaposition progressive d'une, puis d'autres pièces rectangulaires allongées, disposant d'une seul ouverture sur la "coum" (Bazzana 2011: 55), y propone una nueva distinción morfológica entre dos concepciones distintas de la casa, en base al carácter inicialmente compacto o agregativo de su diseño: la maison-bloc y la
} 
este caso de un esquema que en las sociedades islámicas remite de inmediato a los modelos «bereber» y «árabe», planteados por Elizabeth Fentress para el Magreb (2000) y objeto de una reciente reflexión a la luz de las excavaciones en Volubilis/Walila (Fentress \& Limane 2010).

En la misma línea y a partir de su experiencia en el Bajo Alentejo, en Portugal, James I. Boone planteó un modelo hipotético de evolución de la casa rural, aplicando esquemas de sintaxis espacial, desde la casa transicional (siglos VII y VIII) a la islámica de patio (siglos XI y XII) que responderían básicamente a los dos esquemas que venimos describiendo, para confrontarlos con la casa rural postmedieval (siglos XVII al XX), que refleja un cambio radical en la organización doméstica, al convertir la cocina por donde se accede a la vivienda, en el centro nodal y distribuidor de la misma (Boone 2001: 116, fig. 7) (Fig. 2.3).

En el caso de la arquitectura doméstica medieval es posible formular una tipificación más compleja y operativa, que integre nuevas perspectivas de análisis arqueológico de los espacios domésticos. Esta propuesta se plantea desde esquemas gráficos abstractos que si bien connotan ejemplos arqueológicos concretos no los representan de forma fidedigna, siendo esencialmente patrones y no casos particulares $^{16}$.

\subsection{Módulo unicelular ${ }^{17}$ (Fig. 3.1)}

Se define como un volumen autocontenido y plurifuncional, una unidad de edificación con varias áreas de actividad en su interior, sin espacios subsidiarios, que constituye una unidad doméstica simple ${ }^{18}$ a la que se accede directamente desde el exterior. Este esquema, representado aquí en una

maison agglutinante (2011: 59). Según esta nueva propuesta la maison-bloc define las estructuras domésticas complejas, de origen posiblemente agrario, que se conciben unitariamente dentro de un espacio geométrico regular, poniendo como ejemplo el modelo clásico de la casa pluricelular U-71/72 de Monte Mollet. La maison agglutinante, por el contrario, se define como una vivienda construida por etapas a partir de una edificación inicial, tendiendo a definir un patio interior. Para ilustrar este segundo modelo, que puede asemejarse a algunas de las morfologías que se discuten más tarde, se recurre a la casa 203 de Miravet, en Vilafamés (Castellón), para la que se propone un proceso de complejización pas exactamente connu, a partir de una estructura monocelular clásica a la que se irían agregando las diversas dependencias (2011: 58-9, fig. 4 b). Previamente se había interpretado esta vivienda de forma diferente, documentándose varias fases de pavimentación en el interior de algunas estancias, pero considerando que el edificio se construyó de forma unitaria (Bazzana 1992: 298-9, pl. CCLXII).

16 Debo advertir que esta tipificación se representa gráficamente a partir de estructuras modulares construidas en piedra (zócalos y alzados), adobe o tapial, antes que en materiales perecederos y lígneos, si bien puede resultar igualmente aplicable a espacios domésticos realizados con otros materiales y procedimientos constructivos propios de la arquitectura lígnea (Azkarate y Solaun e. p.).

${ }^{17}$ Módulo se utiliza aquí en el sentido que el Diccionario RAE le da en su $2^{\text {a }}$ acepción («Pieza o conjunto unitario de piezas que se repiten en una construcción de cualquier tipo, para hacerla más fácil, regular y económica»).

18 Una unidad autocontenida, «a self-contained unit» (Fentress 2000: 19). estructura confinada por límites construidos en piedra o barro, puede aplicarse también a estructuras realizadas con armadura de postes, excavadas o no (Vigil-Escalera 2000, Azkarate y Quirós 2001, Hamerow 2007: 31 ss.), siendo fundamental en su interpretación social la determinación de las áreas de actividad internas (García 2009: 59, fig. 2).

Un rasgo fundamental de estas unidades domésticas sencillas (al menos de las construidas con zócalo de piedra) es la presencia de un «hogar» como elemento nuclear de la estancia, entendiendo por tal el lugar donde se hace la lumbre y, por extensión, la estructura (construida para tal fin) donde se produce la combustión, aunque su sentido está tan vinculado al ámbito doméstico que la palabra designa igualmente en español la casa y la familia que la habita (Gutiérrez y Cañavate 2010: 131). Es cierto que el área de combustión doméstica puede no tener una estructura definida, ser portátil o sencillamente realizarse en el exterior de la vivienda, aunque suele ser frecuente la presencia de un hogar o al menos un punto de fuego interno. Su posición puede ser variada: central, como suele ser frecuente en contextos protohistóricos (Belarte 2009); cercano a la puerta para asegurar la evacuación de humos como parece ocurrir en las domus terrinee del Foro de Cesar en Roma (Santangeli Valenzani 2011: 131-2); en posición lateral sobre el muro de la fachada o en los testeros cortos de la habitación, buscando siempre la privacidad implícita al giro lateral, en el caso de las unidades domésticas islámicas del Tolmo de Minateda (Gutiérrez y Cañavate 2010: 131 $)^{19}$. Esta posición lateralizada del hogar y la disposición generalizada de la entrada en el lado largo de la crujía parece denotar una cierta preservación de la intimidad en el ámbito doméstico, a diferencia de lo que parece ocurrir en esquemas semejantes documentados en la Protohistoria, donde se observa un predominio de la secuencia axial y la disposición sucesiva de los espacios que remite a formas de vida expuestas (Grau e. p.).

Los procesos de complejización de este tipo de unidad sencilla y autocontenida se pueden producir por dos mecanismos: la compartimentación interna segregando físicamente un espacio concreto de la unidad doméstica o mediante la anexión o subordinación de un nuevo espacio para acoger, en ambos supuestos, actividades específicas y diferenciadas (descanso, almacenaje, etc.). No obstante, tanto los espacios segregados como los anexados funcionan como un único volumen y son interdependientes entre sí,

\footnotetext{
${ }^{19}$ Es decir, en la cara interna y oscura del muro de fachada; el «muro oscuro» por oposición al «muro de la luz», enfrentado a la puerta, donde en la casa de la Kabylia se situaba el telar y la vajilla decorada colgada de la pared (Bourdieu 1972: 47 y 57)
} 

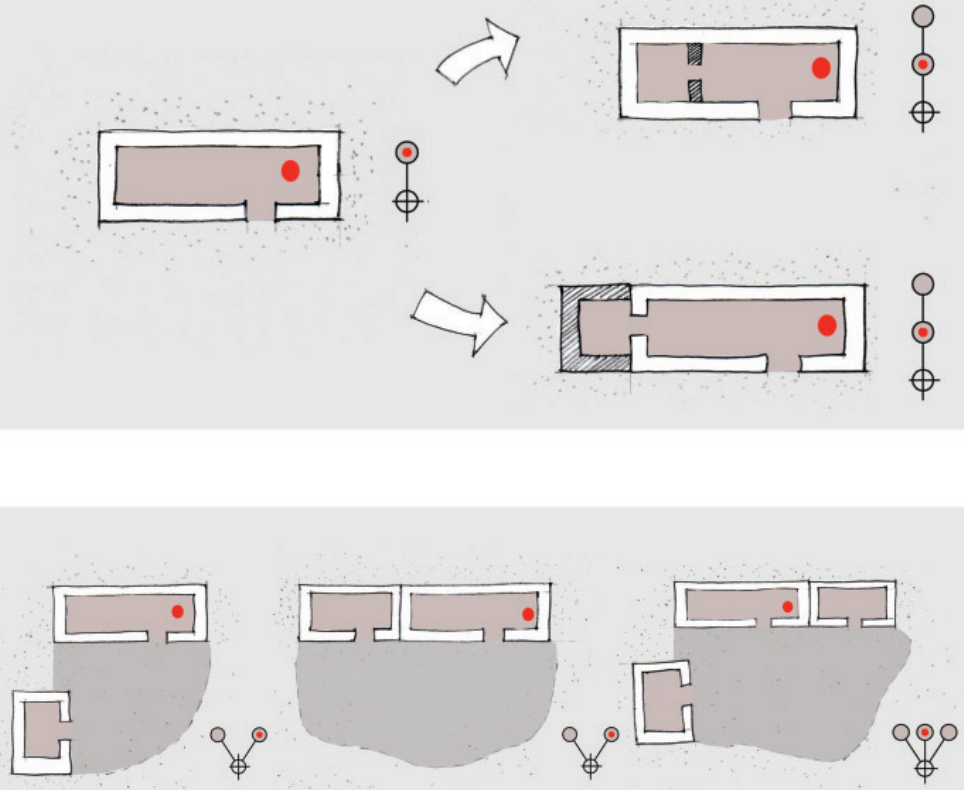

2

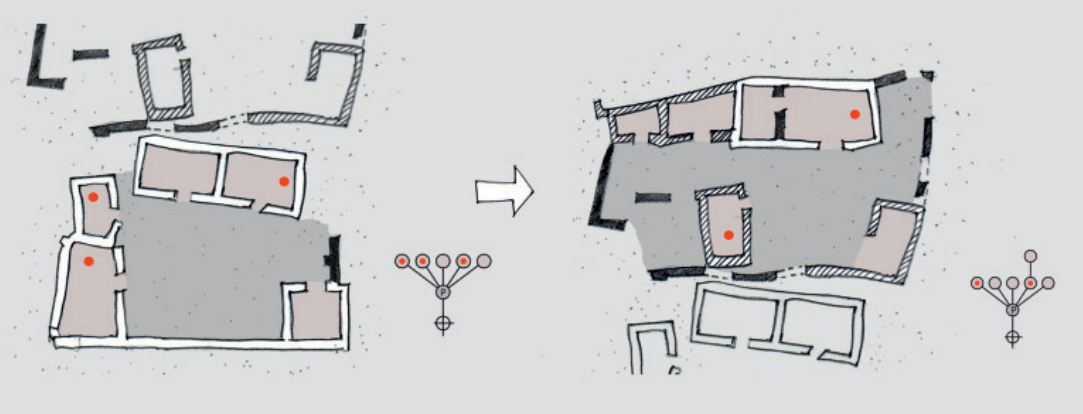

3

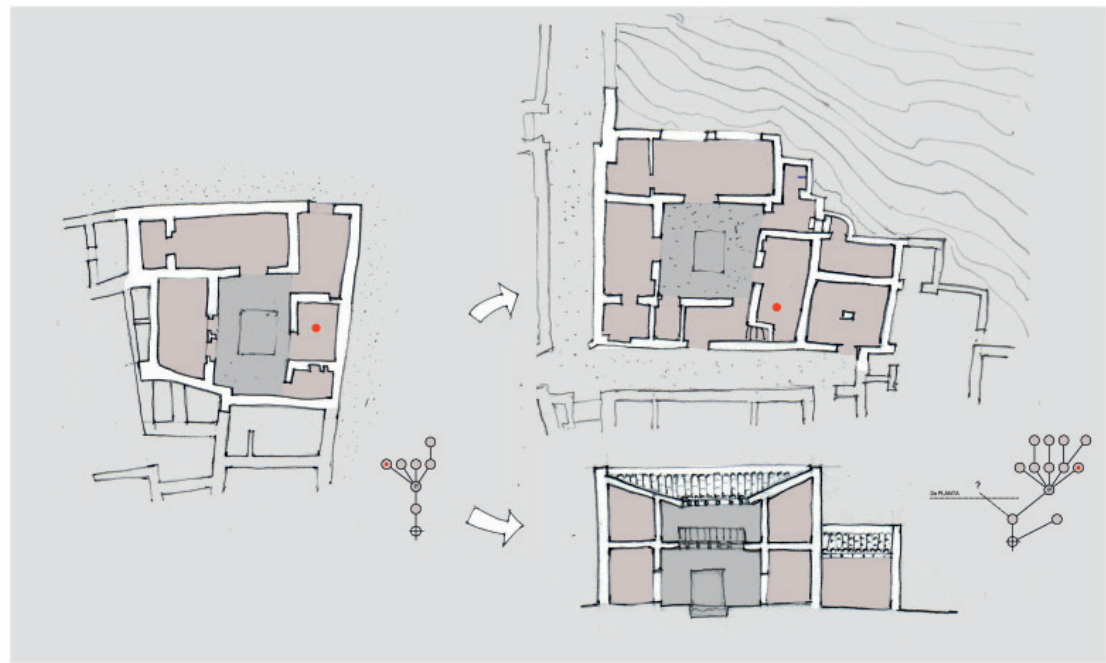

4

Fig. 3. Tipificación de las unidades domésticas y sus procesos de complejización: 1. Módulo unicelular 2. Módulos asociados, 3. Módulos agregados delimitando un «protopatio», 4. Unidad modular compleja estructurada en torno a un patio 
manteniendo el concepto de unidad básica, ya que solo son accesibles desde el modulo principal y nunca directamente desde el exterior.

\subsection{Módulos asociados (Fig. 3.2)}

Volúmenes independientes de funcionamiento asociado. Son módulos arquitectónicamente independientes pero interrelacionados desde un punto de vista funcional. Cada volumen es en sí mismo un módulo unicelular con su propio acceso directo desde el exterior, sin que se establezca ningún tipo de subordinación estructural de unos con respecto a los otros, si bien sus funciones especializadas y diferenciadas sugieren un funcionamiento asociado que los agrega para formar una única unidad doméstica. Esta asociación estructural puede afectar a dos o más módulos que se dispondrán de forma independiente (aislados sin colindar), yuxtapuesta (colindantes generalmente por los testeros cortos de la habitación) o de forma combinada.

La asociación funcional básica suele destinar un módulo a cocina/sala/alcoba y otro a almacén/establo/dependencias auxiliares, como se documenta etnográficamente en el Magreb (Boone 1996: 30, fig. 1.5), aunque la casuística puede ser muy variada. La propia asociación de dos o más volúmenes connota socialmente el área «exterior» que comunica espacial y funcionalmente los módulos asociados, definiendo con límites físicos o simbólicos el espacio exterior que corresponde a dicha unidad domésti$\mathrm{Ca}^{20}$. Los límites simbólicos (disposición de ciertos marcadores de uso social no evidentes o simplemente realización/ exclusión de determinadas actividades funcionales) son por definición evanescentes y raramente se reconocen en el registro material, pero existen indicios arqueológicos que permiten sugerirlos: la composición de los suelos o los ecofactos que indiquen, por ejemplo, actividad ganadera concentrada en esa zona (uso como corral), disposición perimetral de silos y estructuras auxiliares o presencia de cercas y empalizadas que delimiten ciertos ámbitos, como las que aparecen de forma esporádica en algunas construcciones rurales altomedievales, tanto sencillas como complejas (Vigil-Escalera 2003: 288). En cierto modo esta limitación del vacío mediante confines precisos es uno de los primeros elementos que caracterizan la sedentarización de una forma de vida nómada en su proceso de transformación en aldea, y presumiblemente deben demarcar el perímetro del espacio aledaño a la tienda, cuyo uso social

${ }^{20}$ Resulta muy gráfica la definición de la unidad doméstica semicerrada de Oaxaca, donde los hornos, silos/pozos, vertederos y enterramientos demarcan el espacio de la unidad doméstica formada por dos módulos asociados (Winter 1986: 39, fig. 5). estaba perfectamente asignado (Cribb 1991: 387, fig. 7).

Este modelo de estructura doméstica desagregada puede intuirse con diversos grados de fiabilidad en ejemplos peninsulares medievales, como quizá en algunos asentamientos rurales de época visigoda de la provincia de Madrid como Navalvillar (Abad Castro 2006) o La Vega (Alfaro y Martí 2006), donde se observan módulos combinados con diversas funciones (residencia, cocina, almacén, establo, hornos, etc.) dispuestos delimitando un espacio abierto con procesos de sucesiva agregación diacrónica en el ejemplo de La Vega ${ }^{21}$. Más claro es el caso de la unidad doméstica de la fase 1 de Gasteiz (850-950), donde es la disposición del área residencial (interpretada como una longhouse), las estructuras auxiliares del área artesanal, el pozo y los silos destinados al abastecimiento y al almacenaje, $y$, por fin, el recinto ganadero, la que delimita el espacio abierto central que cohesiona y da coherencia unitaria a la unidad doméstica desagregada (Azkarate y Solaun 2009, e. p. $)^{22}$. En asentamientos islámicos resulta por el momento más difícil de determinar, aunque ejemplos como los de $\mathrm{El}$ Molón (Camporrobles, Valencia), en especial los módulos B4 y B2 dispuestos en «L» entre la muralla y la mezquita o los compartimentos alineados del sector A, parecen sugerirlo (Lorrio y Sánchez de Prado 2008: 146-7 y 150-1) 23. Sin embargo, en el caso de la estructuras del sector A también podría tratarse de un ejemplo del siguiente patrón (Módulos agregados delimitando un "protopatio»).

El principal problema de los módulos asociados estriba en reconocerlos como tales y distinguirlos de las tramas urbanas de módulos unicelulares dispersos, como veremos más tarde, puesto que los patrones de organización espacial son muy similares en uno y otro caso. En este punto parece probable que la presencia de hogares en ciertos módulos y su ausencia en otros pueda resultar un indicador eficaz de eventuales asociaciones, junto con el reconocimiento de áreas de actividad ${ }^{24}$.

\footnotetext{
${ }^{21}$ Este enclave rural, en una de cuyas habitaciones se halló un triente del correinado Egica-Witiza datado entre 696 y 702, presenta dos fases reconocidas estratigráficamente que sus excavadoras identificaron como una ampliación sucesiva (Alfaro y Martí 2006: 405), y para las que A. Vigil-Escalera (2006 b: 269-11) propone una interpretación alternativa: un ejemplo de reconstrucción completa de las instalaciones de una unidad doméstica (granja), superponiéndose en parte a los restos de una fase anterior, cuyo modelo reproduce. En cualquier caso, ambas hipótesis son compatibles con el modelo que se discute.

${ }^{22}$ Agradezco a Agustín Azkarate y Jose Luis Solaun el haberme facilitado el original todavía inédito que se publica en este mismo número de la revista, donde desarrollan el estudio de este caso dado a conocer en un trabajo anterior (Azkarate y Solaun, 2009).

23 Vid. Infra, Fig. 7.3.

24 En el caso de Roma altomedieval se propone una solución parecida, al sugerirse que en el caso de estructuras residenciales subdivididas en varios
} 


\subsection{Módulos agregados delimitando un "protopatio» (Fig. 3.3)}

Volúmenes independientes de funcionamiento asociado que se agregan demarcando un espacio central descubierto a modo de patio de imprecisos contornos ("protopatio»). El perímetro de este espacio central no suele estar totalmente definido por los módulos edificados, que adoptan una disposición asociada similar a la propia del patrón anterior, sino que se delimita paulatinamente por tramos de cerramientos lineales (tapias) que terminan por limitar de forma física la circulación y uso del espacio abierto, privatizándolo.

De esta manera se define una organización espacial centralizada y agrupada en torno a lo que se puede considerar, no sólo funcionalmente sino también arquitectónicamente, el patio de la vivienda. Este es, en rigor, un amplio recinto, cuyos contornos irregulares se definen por la propia disposición de los módulos construidos, las traseras de los edificios confinantes y las tapias libres, muy a menudo añadidas en su última fase constructiva. Esta conformación secuencial y diacrónica de las unidades domésticas ofrece una inusual panorámica de la dinámica de los entornos construidos, que contrarresta el estatismo funcional y estructural que suele caracterizar el análisis puramente sintáctico de los espacios (Bermejo 2009: 57-58).

El patrón se reconoció a partir de la excavación estratigráfica de un extenso barrio islámico en la ciudad de Iyyuh (El Tolmo de Minateda en Hellín, Albacete), cuyas secuencias estratigráficas permitieron reconocer los procesos de agregación sucesiva de las unidades domésticas y la definición de un nuevo umbral de permeabilidad (el "protopatio») entre el exterior, público y transitable, y el interior, doméstico y privado (Gutiérrez y Cañavate 2010). Este espacio bisagra anuncia la pauta de privacidad que caracterizará al mundo islámico medieval, y a todo el ámbito mediterráneo antes que a él, y se convierte en el núcleo nodal de la estructura doméstica, un espacio intermedio entre la calle y la casa, cuya privatización se refleja en la demarcación paulatina de sus confines mediante tapias, pero que está lejos todavía del modelo de estructura altamente centralizada que caracteriza a la casa islámica de patio. En este sentido y a diferencia de ésta, con su absoluta preservación de la intimidad y la reclusión femenina representada en el control del único e indirecto acceso al patio, este patrón de unidad doméstica puede presentar

ambientes, aquellas que carecen de hogar pueden identificarse con establos, depósitos o, en el caso de tener pavimentos de madera, dormitorios (Santangeli Valenzani 2011: 130) citando a S. Gelichi y a M. Librenti. más de un acceso desde el exterior ${ }^{25}$. De hecho, el principal proceso de complejización de este patrón doméstico, y el último en la secuencia constructiva, es generalmente la demarcación de los confines del "protopatio» mediante la construcción de las tapias, que definen accesos generalmente oblicuos.

Los diversos módulos, de espaldas al exterior, son accesibles únicamente desde el "protopatio», que constituye el verdadero epicentro de la vivienda y alberga un amplio elenco de actividades productivas y reproductivas de la vida doméstica, como por ejemplo la molienda (molinos de mano), elaboración de alimentos, actividad textil, o cría de animales, ya sea para el uso agrícola (mulas y asnos) o para la alimentación (aves, corderos y cabras). Este patrón de unidad doméstica permite intuir, como se comprobó en el caso del espacio habitacional 2 del Tolmo de Minateda (Gutiérrez y Cañavate 2010: 130-2 y 140, fig. 7), la especialización funcional de los diversos módulos independientes (residencia y reposo, transformación de alimentos, almacenaje, actividad ganadera y artesanal, etc.). No obstante, también sugiere una relativa segmentación social, al reconocerse más de un «hogar» dentro de cada unidad doméstica, con todas las implicaciones sociales que tal hecho puede tener respecto al reconocimiento de células conyugales dentro de un grupo familiar extenso, que cohabita en la misma unidad doméstica en razón de su parentesco. El análisis de varias unidades domésticas del Tolmo de Minateda permitió constatar también una marcada preferencia por construir las estancias principales (cocinas, despensas y alcobas) en los flancos septentrional y occidental de los patios, situando las puertas en los muros meridionales y orientales de las mismas, que se definen así como fachadas principales de la parte de la casa destinada a ser habitada por las personas. De hecho, se constata que en ocasiones el "protopatio» de la vivienda así definida, se cierra del lado opuesto a las fachadas principales (Este o Sur) por el dorso de las estancias igualmente principales de la casa vecina, orientadas ellas mismas hacia el Este o hacia el Sur, al igual que ocurría en las casas bereberes tradicionales de la Kabylia (Bourdieu 1972, 68, n. 75).

\subsection{Unidad modular compleja estructurada en torno a un patio («casa de patio») (Fig. 3.4)}

Los módulos arquitectónicos se disponen en torno a un patio completamente rodeado de volúmenes construidos (crujías), con entrada demarcada espacialmente mediante

\footnotetext{
${ }^{25}$ Vid. Infra, Fig. 4.2.
} 
un trayecto oblicuo (zaguán ${ }^{26}$ en recodo con puertas no alineadas), que al tiempo que regula la circulación segrega visual y espacialmente el patio y garantiza plenamente la preservación de la privacidad y el control de los miembros femeninos del grupo familiar. Este patrón define una unidad doméstica compacta, altamente centralizada y completamente cerrada al exterior, como se aprecia en la ausencia o escasez de ventanas, unicidad de su acceso desde el exterior e incorporación de un nuevo umbral de control de su permeabilidad (el zaguán) entre el exterior y el patio, que jerarquiza notoriamente los diversos niveles de profundidad estructural ${ }^{27}$.

El gráfico topológico resultante del análisis espacial es aún más dendrítico que el precedente, demarcando intensamente la privacidad del patio, que en cierto modo contiene todas las habitaciones (Fentres 1987: 62) al tiempo que las controla. Estas se disponen a modo de crujías longitudinales y no se comunican entre sí, sino directamente con el patio, con la sola salvedad de la segregación en el interior de los salones de espacios destinados al reposo, demarcados mediante tabiques, tarimas, plataformas elevadas o arquerías, conocidos en la literatura de la arquitectura doméstica islámica como alcobas o alhanías ${ }^{28}$. Se trata en consecuencia de una unidad doméstica compleja con especialización funcional, que constituye un nuevo modelo doméstico caracterizado por la aparición de las funciones específicas de zaguán en recodo, alcobas y letrina (Acién 2001, 29), propio de las sociedades islámizadas en todo el Mediterráneo desde al menos el siglo X (Fentress 2000, Missoum 2010).

Aunque la casa de patio es una constante mediterránea desde la Protohistoria a la época romana, más allá del factor común que es el patio, el modelo islámico poco o nada tiene que ver con el concepto axial y el sentido social que tuvo la domus romana, pensada para expresar el rango jerárquico del dominus a través del control de la recepción

26 Término español procedente del árabe andalusí que designa el espacio cubierto situado dentro de una casa, que sirve de entrada a ella y está inmediato a la puerta de la calle. Diccionario RAE. Cfr. Diccionario de arabismos y voces afines en iberorromance (Corriente 2003: s. v. Zaguán).

${ }_{27}$ La única salvedad es la incorporación de un establo en las viviendas rurales de alquerías concentradas y densificadas del siglo XIII en el área murciana, como Siyāsa, donde el ámbito de los animales tiene un acceso directo desde la calle, independiente del tránsito espacial que simboliza el zaguán y, en consecuencia, ajeno a los criterios de privacidad y seclusión que ordenan el resto del espacio doméstico.

${ }^{28}$ Ambos términos, procedentes del árabe, designan el dormitorio o el espacio previsto para dormir en una habitación y son en principio sinónimos, si bien algunos autores se inclinan por alhanía en detrimento del clásico alcoba, muy asentado en la historiografía (Navarro y Jiménez 2007: 240, n. 560). Cfr. Diccionario de arabismos y voces afines en iberorromance (Corriente 2003: s. v. alcoba y alhanía). y los mecanismos de representación pública de las elites (Funari y Zarankín 2001; Bermejo 2007-2008). La vivienda islámica, tanto urbana como rural, responde a un concepto del espacio social totalmente distinto, concebido como la salvaguarda de la privacidad hegemónica en la ideología de la formación social islámica, que se expresa bien en su propia materialidad introvertida (Acién 1998: 937).

La complejización de este modelo de casa, ya de por si compleja, supone la doble dimensión de la especialización funcional de las crujías, de un lado, y de otro, el crecimiento en altura mediante la incorporación de pisos altos o algorfas $^{29}$, que amplían las superficies habitables acogiendo funciones de residencia y almacenaje sobre todo en las casas rurales, generando soluciones de mayor complejidad arquitectónica (Santangeli Valenzani 2011:134). Ambas dimensiones abundan en la creciente diferenciación de ámbitos en el seno de la vivienda y su especialización funcional para desarrollar las distintas actividades que forman parte de la vida doméstica: alcobas para dormir, salones para estar y comer, cocina para elaborar los alimentos, letrina para la higiene personal, despensas, trojes y tinajeros para el almacenaje, establos para los animales y el patio como espacio central de la vida familiar (Adánez 2003: 40). Se diversifican así los espacios internos de la sociabilidad familiar en el ámbito estrictamente doméstico, sin que esta especialización modifique la «diferenciación sexuada global y binaria de los espacios entre un 'dentro' (espacio doméstico privado y femenino) y un 'fuera' (espacio exterior público y masculino)», dicotomía esencial en la que se funda la percepción de los espacios de la casa en la sociedad tradicional islámica (Guichard y Van Staëvel 1995: 47). En este sentido y recogiendo las opiniones de Robert Brunchvig, Manuel Acién señala que la vida privada que rige el urbanismo va más allá de la defensa de la intimidad, del honor familiar o del papel de la mujer, siendo la causa de que «el espacio público sea lo negativo, frente a lo positivo del espacio privado" en la topografía urbana (Acién 2001: 17).

\section{Discusión: procesos diacrónicos y lecturas sociales}

A la luz de lo expuesto, estos patrones morfológicos permiten plantear algunas cuestiones que trascienden la dimensión puramente taxonómica, y anuncian problemas de semiótica doméstica que no discutiremos por extenso en este marco. Uno de los elementos más significativos es el

\footnotetext{
29 Perfectamente atestiguada en espacios domésticos, tanto urbanos como rurales, a partir al menos de los siglos XII y XIII (Navarro y Jiménez 1996; Bazzana 2011: 55).
} 


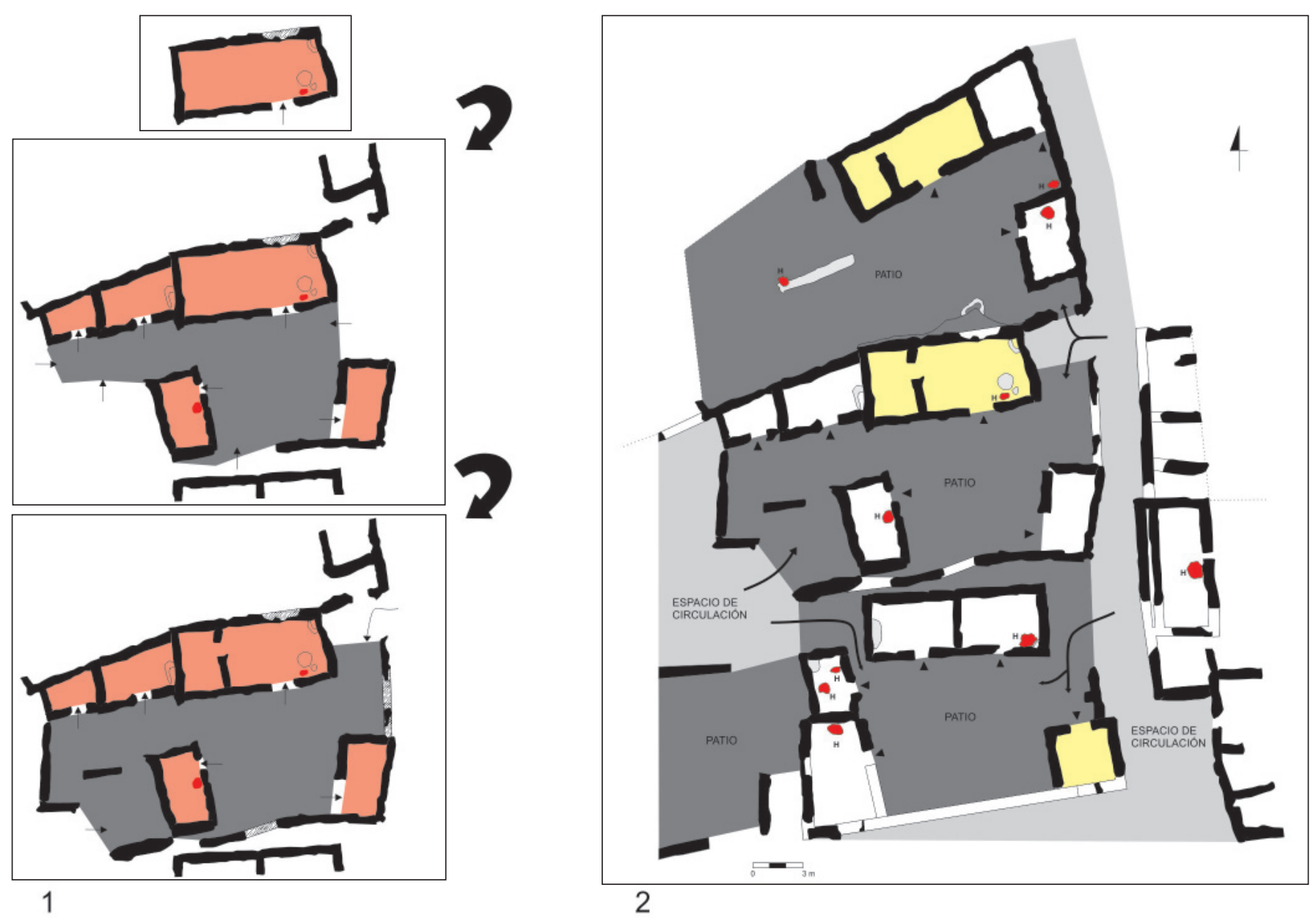

Fig. 4. Procesos diacrónicos: de los módulos unicelulares y asociados a los módulos agregados (Tolmo de Minateda). 1. Evolución constructiva de un espacio habitacional; 2. Manzana septentrional del barrio islámico con indicación de los módulos unicelulares originarios

de la variabilidad diacrónica de las tipologías domésticas, que incurren a menudo en una apariencia estática y en cierto modo anacrónica. Las críticas a este estatismo en el análisis de los entornos construidos, formulada en varios trabajos recientes (Bermejo 2009: 58; Azkarate y Solaún e. p.), se une a la constatación directa del problema planteada por las secuencias estratigráficas del Tolmo de Minateda (Gutiérrez y Cañavate 2010). Sin volver sobre argumentos ya expuestos, resulta significativo destacar que la publicación de las primeras estructuras domésticas autocontenidas del Tolmo y de sus áreas de actividad (Gutiérrez 1999), las convirtieron en un referente del modelo doméstico unicelular o sencillo de época altomedieval, citado a menudo (Vigil-Escalera 2003: 288; Teichner y Schierl 2006: 1256). Sin embargo, la excavación en extensión y la secuencia estratigráfica como instrumento de análisis arqueológico ha permitido a su vez comprender la secuencia de las unidades domésticas, perspectiva igualmente reivindicada en el estudio de los espacios domésticos romanos (Bermejo
2007-2008: 243 ss), llevándonos a afirmar que el modelo de unidad doméstica constatado en el Tolmo durante el Emirato no se ajusta, al menos en su fase final, al esquema monocelular clásico ni al patrón 1 de módulo unicelular definido en este mismo trabajo. Más bien ilustra, como ya hemos señalado, el proceso de transición hacia un modelo estructural de mayor complejidad, basado en la agregación de varias estancias rectangulares en torno a un amplio espacio abierto, que se corresponde mejor con el patrón 3 de módulos agregados delimitando un "protopatio» (Gutierrez y Cañavate 2010: 133).

El ejemplo de la Unidad doméstica 1 de este yacimiento (Fig. 4.1) es particularmente revelador. En él se aprecia como su origen está en un módulo unicelular de gran tamaño con hogar interior, al que se asocian en un momento posterior y simultáneo desde un punto de vista estratigráfico, hasta cuatro módulos (dos de ellos yuxtapuestos y otros dos independientes) denotando un espacio abierto común propio del patrón 2 de módulos asociados, 
pero todavía no segregado del espacio público y en consecuencia transitable. Estos módulos independientes evidencian una creciente especialización funcional que destina un módulo preferente por su orientación (al oeste del complejo pero accesible desde oriente) a la cohabitación familiar, como parece sugerir su hogar, mientras que las dos estructuras anejas al modulo originario pueden tener un valor polivalente (residencia o despensa, como sugiere el mobiliario cerámico), y el módulo más oriental, construido contra la terraza de la siguiente vivienda y dotado de un amplio vano inusualmente orientado al oeste, podría acoger el establo o almacén. Esta especialización espacial refuerza el carácter unitario de las estructuras que deben ser interpretadas como parte de una única unidad doméstica semicerrada, al modo de M. Winter (1986).

La tercera fase refleja claramente que la evolución hacia un patrón de módulos agregados delimitando un "protopatio» ha culminado con éxito, como se aprecia en el confinamiento del espacio común definido por el uso familiar, consistente en un muro que flanquea la calle oriental, con un vano que canaliza la circulación de forma oblicua y que en este caso actúa como distribuidor de dos viviendas colindantes, y un amplio vano en el frente opuesto de la vivienda, con un muro que actúa de parapeto visual y enfatiza la privacidad del patio. Al mismo tiempo el tabicado interno de la amplia estancia originaria define, a mediados del siglo IX, el sentido de la alcoba, en tanto que aposento específico para el descanso demarcado del espacio de estar y comer, que constituye ahora el resto de la sala/cocina.

En este sentido resulta igualmente ejemplificador el edificio AI de El Molón, en Camporrobles (Valencia), donde se han determinado dos fases constructivas: una primera con dos estancias contiguas yuxtapuestas, accesibles directamente desde el espacio abierto delantero; y una segunda en la que se elimina el muro medianero entre ambas estancias y se tapia uno de los accesos, convirtiéndola en una única y alargada crujía, al tiempo que se habilita «un pequeño espacio que queda separado del resto por dos tabiques construidos sobre los niveles de relleno acumulados en su interior», que únicamente puede ser interpretado como una alcoba semejante a las de El Tolmo (Lorrio y Sánchez de Prado 2008: 150 y 151, fig 5.2) ${ }^{30}$. Esta segregación interna de la estructura rectangular y su propia conceptuación espacial, subordinada claramente al aposento principal y dependiente de éste en un trayecto sucesivo,

\footnotetext{
${ }^{30}$ Un ejemplo semejante parece intuirse en la casa M/52/61 de Mollet, donde una larga crujía se tabica internamente al tiempo que se clausura una de sus puertas (Bazzana 1992: II, Pl. CCLXXI, 397).
}

refuerza la paulatina diferenciación de dos ambientes funcionales en el espacio residencial (la alcoba para dormir y la sala para estar) introduciendo un segundo nivel de profundidad estructural. Esta separación será característica de las viviendas a partir de los siglos X y XI, pudiendo ser leída, o al menos eso creo, en términos de «islamización» social, esto es, de adquisición y generalización de unos hábitos sociales islamizados que se reflejan y se refuerzan en el espacio doméstico.

La figura 4.2 muestra la articulación completa de la manzana con una trama de unidades domésticas alineadas y colindantes, en las que se han coloreado los módulos unicelulares originarios ${ }^{31}$, que corresponden, de norte a sur, a dos construcciones islámicas ex nouo y al reaprovechamiento de un ingreso a la basílica visigoda ya expoliada, que permanecía en pie y se integró como posible estancia aneja en la vivienda más meridional, que seguramente utilizó también como tapia el muro perimetral del aula basilical, hoy perdido (Gutiérrez y Cañavate 2010) ${ }^{32}$.

Sin entrar en un análisis profundo de los aspectos sociales que estos datos sugieren, no quiero dejar de señalar que una misma expresión arquitectónica sencilla, como el módulo unicelular, es interpretada en diversos contextos históricos y sociales de formas muy diferentes. Así, en el Medievo islámico, su semejanza contrastada con espacios domésticos autocontenidos bereberes, estudiados por la etnografía, obliga a tomar en consideración, con todas las precauciones lógicas (Fentress 2000, 16-21), su eventual relación con estructuras familiares extensas y una fuerte solidaridad comunitaria basada en el parentesco. Por el contrario, en el Lacio altomedieval similares viviendas constituite da un unico ambiente di picole o medie dimensioni testimonia que ci troviamo di fronte a residenze relative a una singola familia nucleare, all'interno della quale era prevista una completa promiscuità degli spazi di vita (Santangeli Valenzani 2011: 129). Por otro lado, la singular agregación que refleja el tercer patrón analizado y la geminación de estancias con hogar en las unidades domésticas, no puede sustraernos del eventual reconocimiento de células conyugales dentro de un grupo familiar extenso, que cohabita en la misma unidad doméstica en razón de su parentesco. La potente reflexión de Pierre Bourdieu a propósito de la organización doméstica de la sociedad kabileña no puede ser ignorada:

\footnotetext{
${ }^{31}$ La división de alcobas es generalmente posterior y corresponde a la fase final de organización de la unidad doméstica, no así el espacio demarcado por el módulo original.

32 Un proceso agregativo comparable ha sugerido recientemente A. Bazzana (2011: 58-9, fig. 4 b) para la casa 203 de Miravet. Vid. Supra, n. 15).
} 

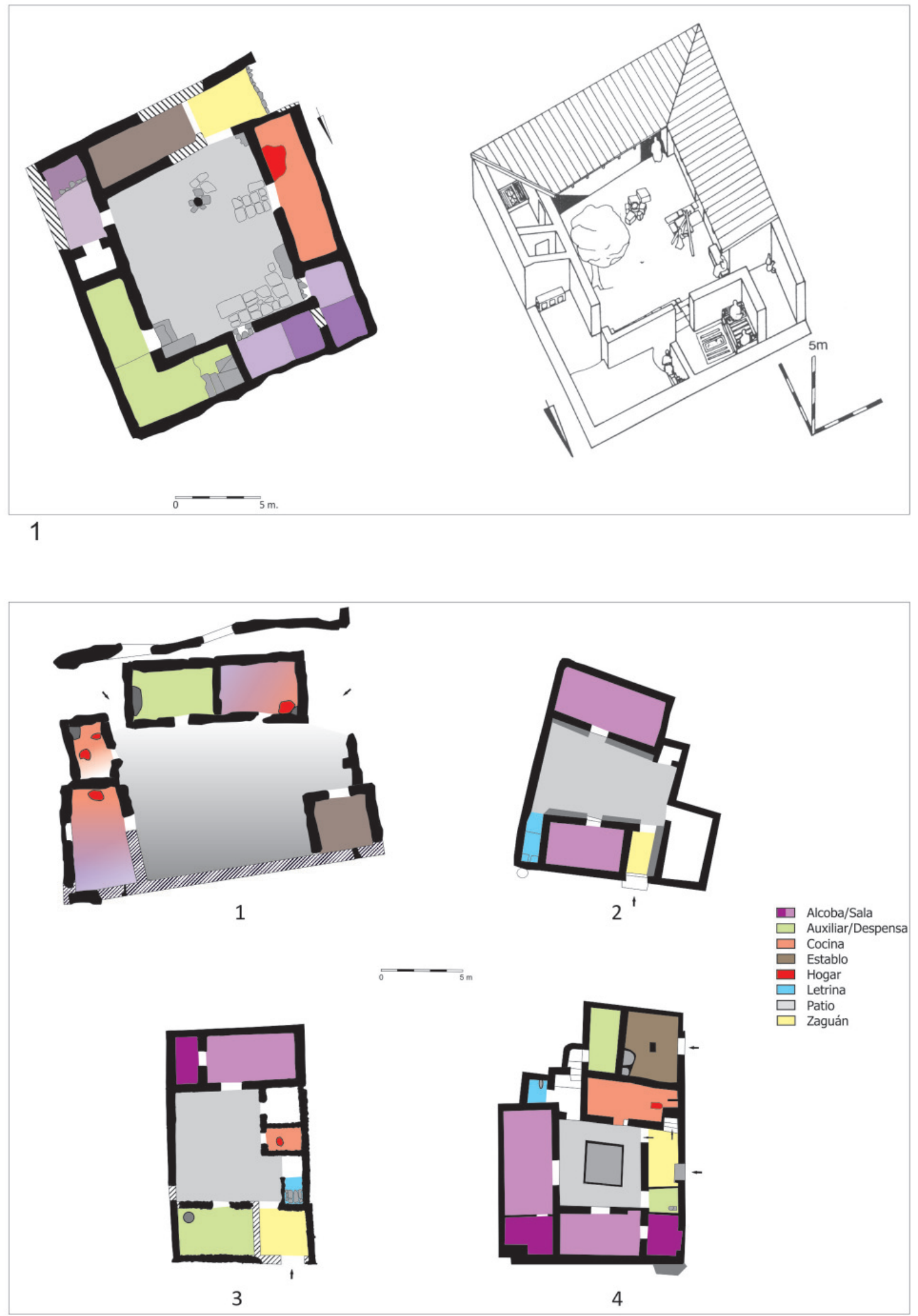

2

Fig. 5. La casa de patio islámica: 1. Casa I de Sétif (según Fentress 1987: figs. 4 y 5, modificada); 2. Proceso de especialización funcional de los ambientes: 1. Tolmo de Minateda (E.H 2, Gutiérrez y Cañavate 2010: fig. 7), 2. Casa V4 de Pechina (según Castillo y Martínez 1990: 121, modificada), 3. Casa 6 del arrabal occidental de Córdoba (según Cánovas Ubera et alii 2008: 208, modificada), 4. Casa 6 de Cieza (según Navarro y Jiménez 2007: fig. 61, modificada) 
La célula familiar es una unidad fundamental: unidad económica de producción y consumo, unidad politica en el seno de la confederación de familias que es el clan, unidad religiosa en última instancia puesto que cada hogar es lugar de culto común (ritos de iniciación, del hogar, de los espiritus familiares, etc.). La cohesión se ve reforzada por la unidad del asentamiento - las casas de los descendientes de un mismo antepasado se agrupan generalmente alrededor de un patio común-y por la comensalía. (Bourdieu 2007: 58) ${ }^{33}$.

Sin embargo, como hemos señalado Patrice Cressier y yo misma (2009: 152): On a parfois fait appel à l'anthropologie pour rechercher l'origine de cette structure domestique, allant même jusquà vouloir identifier l'appartenance ethnique des populations concernées. Là aussi, l'archéologie nous avertit du risque qu'il y aurait à systématiser de tels parallélismes; le problème est beaucoup plus complexe, ce type de maisons simples (ou unicellulaires) étant documenté dans des contextes aussi bien wisigothiques tardifs quislamiques de première époque, et en milieu tant urbain que rural (et, dans ce cas, que le peuplement ait été indigène ou tribal). La lectura social del espacio doméstico (su dimensión semiótica, que no vamos a abordar aquí) es compleja y poliédrica y no permite una traducción mecánica en términos de etnicidad.

Por fin, el patrón de la unidad modular compleja estructurada en torno a un patio, la llamada "casa de patio», remite morfológicamente al modelo altamente centralizado que E. Fentress (2000: 21) denominó «modelo árabe» y que cabría considerar, en un sentido más preciso, la unidad doméstica propia de la formación social islámica (Acién 2001), en tanto que caracteriza la mayoría de las sociedades islamizadas (con independencia de su origen étnico) en todo el Mediterráneo desde mediados del siglo IX. La introducción y progresiva generalización de este nuevo modelo doméstico de origen mediterráneo, ajeno a la tradición romana, desemboca en una homogeneización morfológica y funcional de las estructuras domésticas, que puede ser interpretada como la materialización de la islamización social completa ${ }^{34}$. Creemos, en suma, que la generalización de la "casa de patio» puede ser un buen indicador del ritmo y peculiaridades de dicho proceso (Cressier y Gutiérrez 2009:151). La casa de patio islámica, representada en la figura 5.1 por la casa I de Sétif (la

\footnotetext{
${ }^{33}$ La negrita es mía.

34 Sobre el sentido y definición de la formación social islámica y sobre el concepto de islamización social, en tanto que adopción de las formas sociales, económicas e ideológicas de dicha formación social, más allá de la práctica religiosa, debe verse M. Acién (1998), en especial para sus implicaciones en la concepción de la vivienda como salvaguarda de lo privado y traducción de un modelo familiar, pp. 937-9.
}

romana Sitifis en Argelia), datada entre la segunda mitad del siglo X y la primera del XI d. C. y estudiada en el conocido trabajo de Elizabeth Fentress «The house of the prophet: North African Islamic Housing» (1987), muestra claramente sus características generales: la distribución en torno al patio de crujías independientes entre sí, la marcada privacidad connotada en el zaguán en recodo y la definición de ambientes especializados (fundamentalmente las salas, en este caso con una tarima de obra que demarca la alcoba; la cocina, la despensa-almacén y el establo).

En el caso de al-Andalus, desde mediados del siglo VIII en el arrabal de Šaqunda en Córdoba (Casal 2008) y durante el siglo IX en Iyyuh / El Tolmo de Minateda (Gutiérrez y Cañavate 2010), algunos entornos construidos muestran ya ciertos indicios de interacción entre patrones domésticos distintos, plasmados sobre todo en la organización en módulos alargados abiertos a amplios recintos descubiertos, si bien existen fórmulas parecidas también en contextos visigodos. En Šaqunda resulta más difícil reconocer la funcionalidad de los espacios, pero las unidades domésticas de El Tolmo denotan ya claramente, a finales del siglo IX, una creciente especialización de las estancias, con marcada preeminencia de los módulos residenciales que integran todavía la función culinaria, en una lectura social muy próxima al patrón autocontenido de la casa unicelular. No obstante, comienzan ya a incorporar ambientes auxiliares tales como despensas y establos, e incluso (en el caso del espacio habitacional 2) una cocina común, que denota un estrecho funcionamiento comunitario, con independencia de que la presencia de estancias con hogar propio sugiera también la existencia de células conyugales independientes en el seno del grupo doméstico que cohabita (Fig. 5, 2.1) ${ }^{35}$. En cualquier caso el modelo de casa islámica de patio aparece ya nítidamente representado a mediados del siglo IX en yacimientos urbanos como Bâŷyanna/Pechina (Fig. 5, 2.2), donde incorpora claramente la sala, la letrina como equipamiento sanitario y el zaguán en recodo como marcador de reclusión femenina y privacidad. El modelo se consolida en época califal en los ensanches urbanos de Córdoba, donde comienza a generalizarse la alcoba individualizada de la sala y la cocina como

\footnotetext{
${ }^{35}$ Este es el único caso donde se ha podido individualizar una verdadera cocina, entendiendo por tal un volumen arquitectónico destinado exclusivamente a la elaboración de los alimentos, frente al resto de estancias residenciales con hogar y espacio de permanencia y reposo. El reducido tamaño de ésta $\left(6 \mathrm{~m}^{2}\right)$ frente a las otras (de 15 a $20 \mathrm{~m}^{2}$ ), la presencia de un vasar y dos grandes hogares (uno expuesto frente a la puerta, en lugar de la posición acodada que caracteriza los restantes) refuerza esta impresión (Gutiérrez y Cañavate 2010: 131). Al menos en esta casa parece que las mujeres del grupo gestionaban la elaboración del alimento familiar de forma comunitaria o en un espacio común.
} 


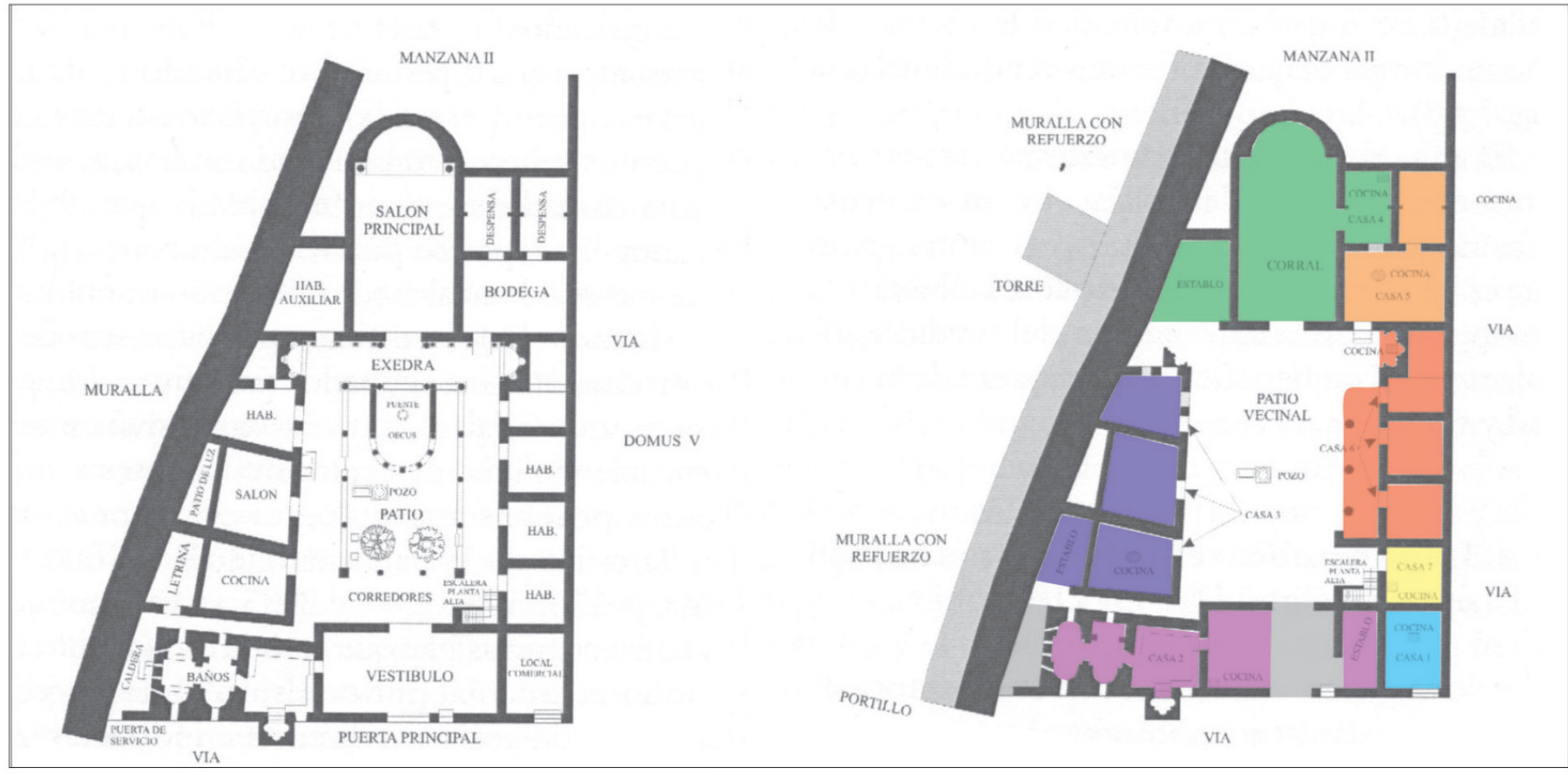

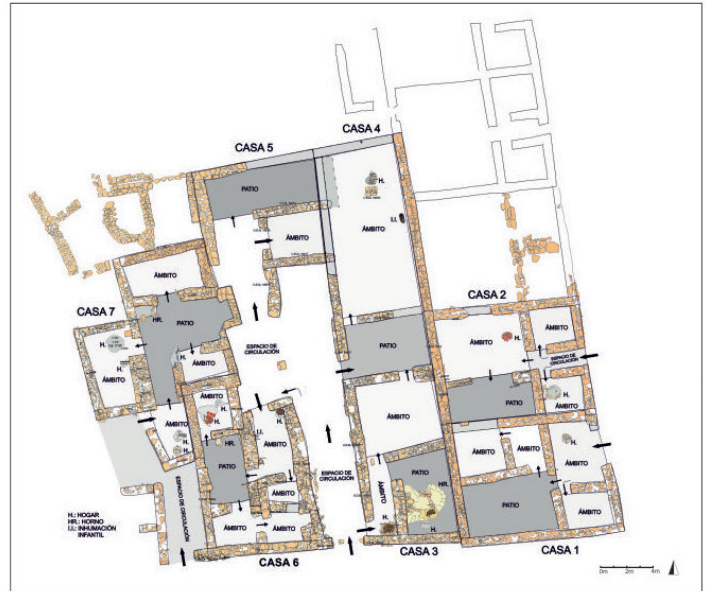

2

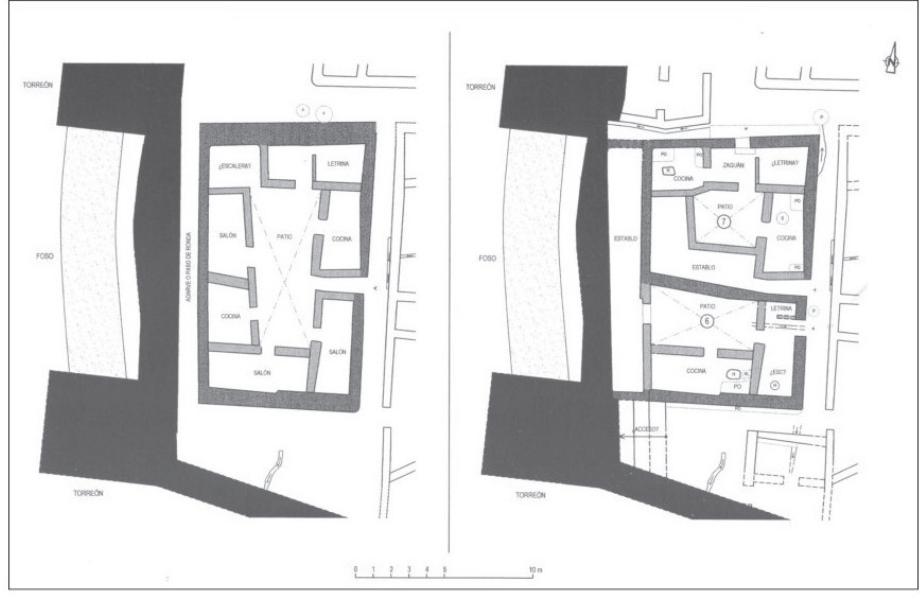

3

Fig. 6. Procesos diacrónicos: agregación y segregación: 1 Compartimentación de la Domus de los Mármoles en época visigoda, Morería, Mérida, ss. IV y VII (según Alba 2007: figs. 8 y 9, modificado), 2. Transformación del barrio visigodo de Recópolis en el siglo VIII (cedida por Olmo, 2011: fig. 2); 3. División de una vivienda en Villa Vieja, Calasparra, Murcia, s. XIII (según Pozo et alii 2002: fig. 16)

espacio propio y exclusivo para las actividades culinarias, apareciendo el pórtico (Fig. 5, 2.3) ${ }^{36}$.

La identificación entre ciudad e ideología islámica implica igualmente la generalización de este nuevo modelo

36 La escasa especialización de las habitaciones sin desarrollo de alcobas diferenciadas y la ausencia de patios de andenes bien estructurados, han sido utilizadas como criterios cronológicos para sugerir el origen más antiguo (siglo IX) del primer crecimiento urbanístico en el sector occidental, extramuros de Córdoba (Acién y Vallejo 1998: 121) de casa compleja con patio central, hasta suplantar definitivamente otros esquemas domésticos de mayor simplicidad, que perviven en los ambientes rurales hasta fechas más avanzadas. De esta forma, los contornos diferenciales de los medios urbano y rural terminan por difuminarse, alcanzándose tal homogeneización de las soluciones urbanísticas, morfológicas y constructivas, que resulta imposible reconocer el carácter urbano o rural de muchas unidades domésticas almohades (siglo XIII) por la materialidad 
de sus expresiones arquitectónicas concretas; es el caso de las unidades domésticas de la alquería de Siyāsa/Cieza en Murcia (Fig. 5, 2.4), donde se alcanza un alto grado de especialización funcional, que incluye alcobas y salones, cocina, letrina, tinajero, despensa y un piso alto, a más de un establo de acceso independiente. Nada distingue estas casas, ni tan siquiera en sus equipamientos ornamentales, de otras viviendas urbanas de época almohade, como las de Mértola, Saltés o la propia Murcia ${ }^{37}$.

Esta lectura diacrónica debería servir para matizar el estatismo antropológico que a menudo se infiere de los modelos taxonómicos (los propios incluidos) y que termina por caracterizar antropológicamente las sociedades estudiadas mediante arquetipos ${ }^{38}$. De hecho, la "casa de patio" islámica es uno de esos arquetipos que atraviesa toda la historia de al-Andalus, y cuya alargada sombra se proyecta incluso en su derrota y sumisión al nuevo orden feudal. Es innegable que el ordenamiento de los entornos constructivos mudéjares y moriscos del Reino de Valencia (siglos XIV a XVI) se expresa de forma muy diferente a otros sistemas de organización de los espacios domésticos medievales, como el «conveniente para la reproducción de un sistema cristiano, feudal, occidental- donde las relaciones de parentesco juegan un papel muy secundario en la organización social» (Torró 2009: 212); pero las afirmaciones de que las pautas de desarrollo de las unidades de residencia musulmanas «no se modifican de manera sustancial entre los primeros momentos de presencia musulmana en alAndalus y la expulsión de los moriscos» y que estas pautas "por otra parte, son comunes a una gran parte del mundo islámico y han perdurado hasta la actualidad en el Magreb y en otras regiones, tal y como lo demuestra la amplia literatura etnográfica» (Torró 2009: 206), refuerzan una imagen estática de los espacios domésticos medievales que está lejos del análisis de los mismos que aquí se ha expuesto. Más allá de las similitudes morfológicas entre los

${ }^{37}$ Reflexión conjunta con Patrice Cressier, en el marco del material preparatorio del trabajo publicado por ambos en 2009. Sobre los espacios domésticos de estos enclaves puede verse el volumen general sobre Casas y palacios de al-Andalus. Siglos XII-XIII, editado por J. Navarro (1995) y en particular sobre Murcia (Jiménez y Navarro 1997, Navarro 1991) Saltés (Bazzana y Cressier 1989, Bazzana y Bedia 2009) o Mértola (Macias 2006).

38 En cualquier caso la necesidad de una perspectiva diacrónica no debe ser confundida con una concepción evolucionista y lineal de la evolución del espacio doméstico medieval desde las soluciones más sencillas (el módulo unicelular) a las más complejas (la casa de patio). Las diversas propuestas morfológicas aparecen y se relacionan en diversas épocas y contextos económicos y sociales, tanto urbanos y rurales. De hecho se podrían intuir ciertos procesos agregativos que explican la asociación y agregación de módulos unicelulares, pero raramente estos ejemplos devienen en unidades modulares complejas estructuradas en torno a un patio, o lo que es lo mismo, en "casas de patio». Bazzana también ha cuestionado la explicación evolucionista (2011: 55). entornos construidos de forma autónoma en el temprano al-Andalus y las casas moriscas, rurales y sometidas, de su final, debe haber profundas diferencias en la organización y el uso social del espacio que tenemos que comenzar a reconocer, trascendiendo una similitud sintáctica que en ocasiones es más aparente que real y puede estar condicionada por soluciones espaciales, que no necesariamente sociales, comparables ${ }^{39}$.

Si bien nos hemos referido con preferencia a los procesos diacrónicos agregativos, esto es, aquellos que permiten reconocer el paso de, por ejemplo, módulos unicelulares y asociados a módulos agregados, no conviene olvidar que el análisis estratigráfico nos permite reconocer igualmente mecanismos de segmentación que nos pueden informar sobre procesos sociales de gran interés y complejidad; así por ejemplo, la conocida y bien estudiada fragmentación de una domus emeritense, de gran tamaño y propiedad privada, en un conjunto de siete viviendas sencillas (de una, dos, tres o cuatro habitaciones en la planta correspondiente al piso bajo) con uso comunitario del antiguo peristilo, ahora transformado en el patio de una casa de vecindad, nos informa sobre el final del modelo de vivienda señorial y sobre eventuales procesos de fragmentación de la propiedad en ciertos sectores urbanos durante la época visigoda (Alba 2007. Fig. 6, 1).

Un panorama igualmente significativo ofrece el singular proceso de densificación poblacional constatado por Lauro Olmo en Recópolis, con la compartimentación y remodelación de dos grandes viviendas y edificios comerciales visigodos próximos al área palatina; en este caso, durante el siglo VIII se constata una compartimentación interna de las antiguas construcciones visigodas, respetando sus confines, pero reordenando completamente el espacio habitacional para alojar siete nuevas viviendas (Olmo 2011: 42-3. Fig. 6, 2) ${ }^{40}$. Por fin, en un contexto totalmente distinto, la división de una amplia vivienda en dos más pequeñas con apropiación del pasillo de ronda de la muralla, en la fase final de la alquería de Villa Vieja en Calasparra, Murcia (Fig. 6, 3), ilustra la relación entre espacios domésticos y conflicto social. Esta división puede interpretarse, de acuerdo con los investigadores responsables de su estudio con un proceso de segmentación familiar y fragmentación de su patrimonio (Pozo et alii 2002: 165),

\footnotetext{
39 Vid. infra Fig. 8. En este sentido no parecen comparables las opciones económicas impuestas a las poblaciones rurales en el caso mudéjar con aquellas derivadas de la lógica social comunitaria que caracterizó la organización de los espacios rurales en el temprano al-Andalus y cuya cronología inicial por otra parte tampoco conocemos bien (Gutiérrez Lloret 2011: 38-9).

${ }^{40}$ Agradezco a Lauro Olmo y al equipo de Recópolis la ilustración de dicho proceso.
} 


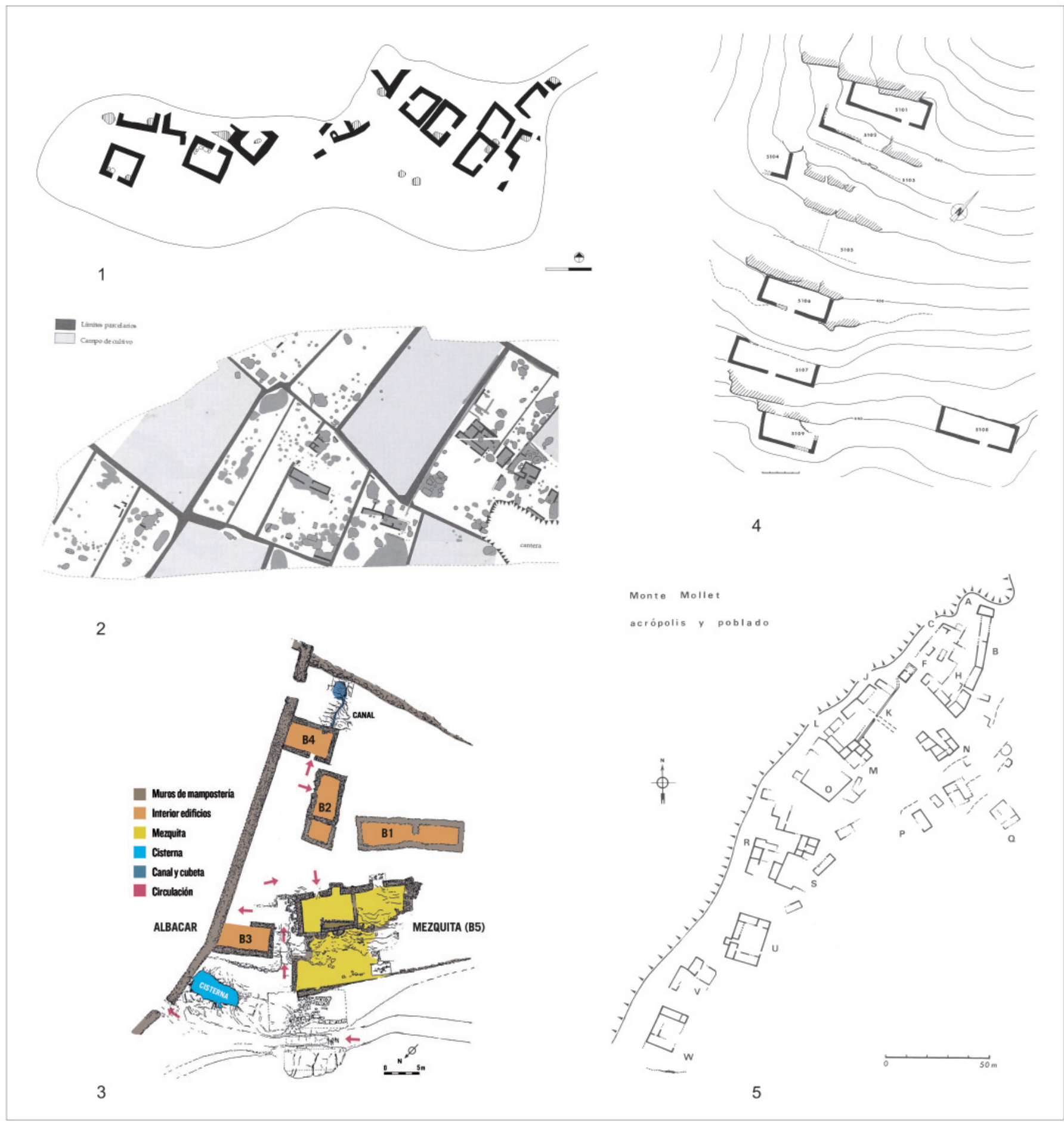

Fig. 7. Unidades domésticas dispersas: 1. Ponta do Castelo, Carrapateira, Aljezur, ss. XII-XIII (según Gomes 2011: fig. 5); 2. Estructura parcelaria de Gózquez, Madrid, 530-750 d. C. (según Vigil-Escalera 2006 b: fig. 8), 3 El Molón, Camporrobles, Valencia, ss. IX-X (según Lorrio et alii 2009: 51), 4. Uxo III, sector II, Castellón, s. XIV- xv (según Bazzana 1992, II: fig. 420) y 5. Mollet, Villafamés, Castellón, ss. VII-IX (según Bazzana 1992, II: fig. 388)

pero también con la concentración de la población musulmana durante el Protectorado castellano (1243-1267) y la consiguiente densificación de la trama urbana, que trajo consigo la instalación de viviendas de tipo elemental, mucho más reducidas, desbordando incluso el cerco murado (Pozo et alii 2002: 157) ${ }^{41}$.

${ }^{41}$ Casos de partición de viviendas han sido estudiados en Siyāsa y Murcia como ejemplos de saturación (Navarro y Jiménez, 2011). 


\section{LA SINTAXIS: FORMAS DE AGRUPACIÓN DE LAS UNIDADES DOMÉSTICAS EN TRAMAS}

La tipificación de las unidades domésticas tiene un valor descriptivo pero su compresión requiere trascenderlas como unidades básicas de análisis y situarlas en el marco de una estructura espacial más compleja. De eso se ocupa precisamente la sintaxis: de analizar la organización de las formas construidas (privadas y públicas), en relación al espacio intersticial, y su forma de agrupación en tramas ${ }^{42}$.

De una forma concisa podemos considerar que la agrupación de las estructuras domésticas puede recurrir a dos formas de organización espacial básicas: la dispersa o diseminada y la colindante, que puede presentarse a su vez en organización lineal, agrupada o en trama ${ }^{43}$. Para ilustrarlas gráficamente hemos elegido, de forma consciente, ejemplos de asentamientos medievales de diversa cronología y contexto social, ya que se trata de enfatizar las categorías sintácticas de los procesos de agregación, antes que de definir sus semánticas sociales, que, como venimos advirtiendo, pueden ser muy diferentes a pesar de su similar estructura. Esta clasificación pretende únicamente normalizar las categorías descriptivas de las formas de agrupación de las unidades domésticas, al menos en este nivel instrumental.

\subsection{Organización espacial dispersa}

Las organizaciones dispersas son aquellas en las que las unidades domésticas se diseminan por el espacio sin compartir paredes medianeras ni colindar, quedando aisladas e independientes entre sí. Los ejemplos propuestos engloban desde aldeas donde se reconoce la estructura parcelaria como Gózquez, que ejemplifica la categoría de asentamiento agregado altomedieval formulada por A. Vigil-Escalera $^{44}$ (Fig. 7, 3), hasta asentamientos concentra-

\footnotetext{
42 Agradezco las precisas observaciones de Débora Kiss sobre la disposición del tejido urbano y las organizaciones en trama.

43 Sobre este particular puede resultar clarificadora, aunque no totalmente coincidente, la propuesta de Francis D. K. Ching (2006: 189 ss).

${ }^{44}$ No deben confundirse los formas de organización espacial que aquí se formulan, con las categorías arqueológicas del poblamiento rural («disperso», "agregado" y "concentrado») formuladas por Alfonso Vigil-Escalera (2006 a), aunque en ambos casos se utilice el epíteto "disperso». En rigor, la clasificación de Vigil-Escalera se refiere en los dos primeros casos a formas de asentamiento abierto, sin confines significativos entre el área residencial y los espacios de trabajo, equiparables a granjas (una única entidad productiva de carácter singular compuesta generalmente por una unidad doméstica), aldeas (entre 12 y 24 unidades domésticas) y, en el tercer caso, al asentamiento concentrado que engloba conglomerados urbanos de variada naturaleza, desde pueblos a ciudades. En rigor, al referirme yo a agregaciones de unidades domésticas en "tejidos» urbanos, sólo podría contemplar como unidad de análisis sus categorías de poblamiento "agregado" y "concentrado», que implican a varias unidades domésticas, y nunca la de poblamiento «disperso" que se aplica a una única
}

dos de carácter fortificado y diversas cronologías como el temprano poblado castellonense de Monte Mollet (Fig. 7,

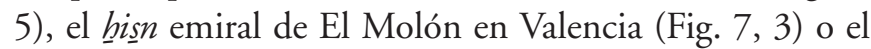
poblamiento bajomedieval de Uxó III (Fig. 7, 4), pasando por el asentamiento de pescadores de Ponta do Castelo, que ocupa una península del sur de Portugal entre los

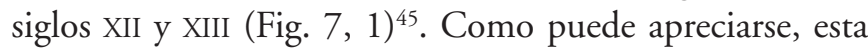
forma de organización espacial se produce tanto con módulos unicelulares (Ponta do Castelo y Uxo III), como con módulos asociados (El Molón) o incluso agregados delimitando un "protopatio» (Monte Mollet), en diversas cronologías.

\subsection{Organizaciones espaciales colindantes 0 contiguas}

Las organizaciones colindantes o contiguas son aquellas que comparten alguna pared medianera y según su organización pueden ser de tres tipos:

\subsubsection{Organización agrupada}

Aquella en que las unidades domesticas se reúnen en grupos, apiñándose entre sí, de forma que aunque dejen intersticios entre ellas establecen una relación basada en la proximidad o en el contacto físico, lindando parcialmente (Ching 2006: 189). Formas de organización similar son frecuentes tanto en asentamientos urbanos, como la ciudad preislámica siria de Umm al-Jimal, ss. V-VII (Fig. 8, 1), como rurales ejemplificados aquí en la aldea visigoda de Cuarto de las Hoyas en Salamanca (Fig. 8, 3), la alquería emiral de Peñaflor en Jaén (Fig. 8, 2) y el asentamiento morisco de L'Adsubieta en Alicante (Fig. 8, 4), todos ellos caracterizados por un patrón de unidad doméstica próximo al de módulos agregados delimitando un "protopatio». El caso de Umm al-Jimal es particularmente significativo ya que su conocida planta se suele traer a colación como ejemplo de urbanismo preislámico desagregado (Vries 2000) y del que recientemente Alan Walmsley ha sugerido que refleja la ruralización del entorno urbano, al argumentar que este modelo de casa con patio fue originariamente una forma rural bizantina que se adaptó al contexto urbano en la temprana época islámica (Walmsley 2007: $131-32)^{46}$.

unidad doméstica. En consecuencia el sentido del epíteto «disperso» aplicado a formas de organización espacial, difiere completamente del asignado como categorización del poblamiento rural.

${ }^{45}$ Las referencias bibliográficas precisas sobre estos asentamientos y la procedencia de sus planimetrías, así como las referencias cronológicas precisas, se indican en adelante en los pies de las figuras correspondientes.

${ }^{46}$ Agradezco a James L. Boone que llamase mi atención sobre este argumento. 


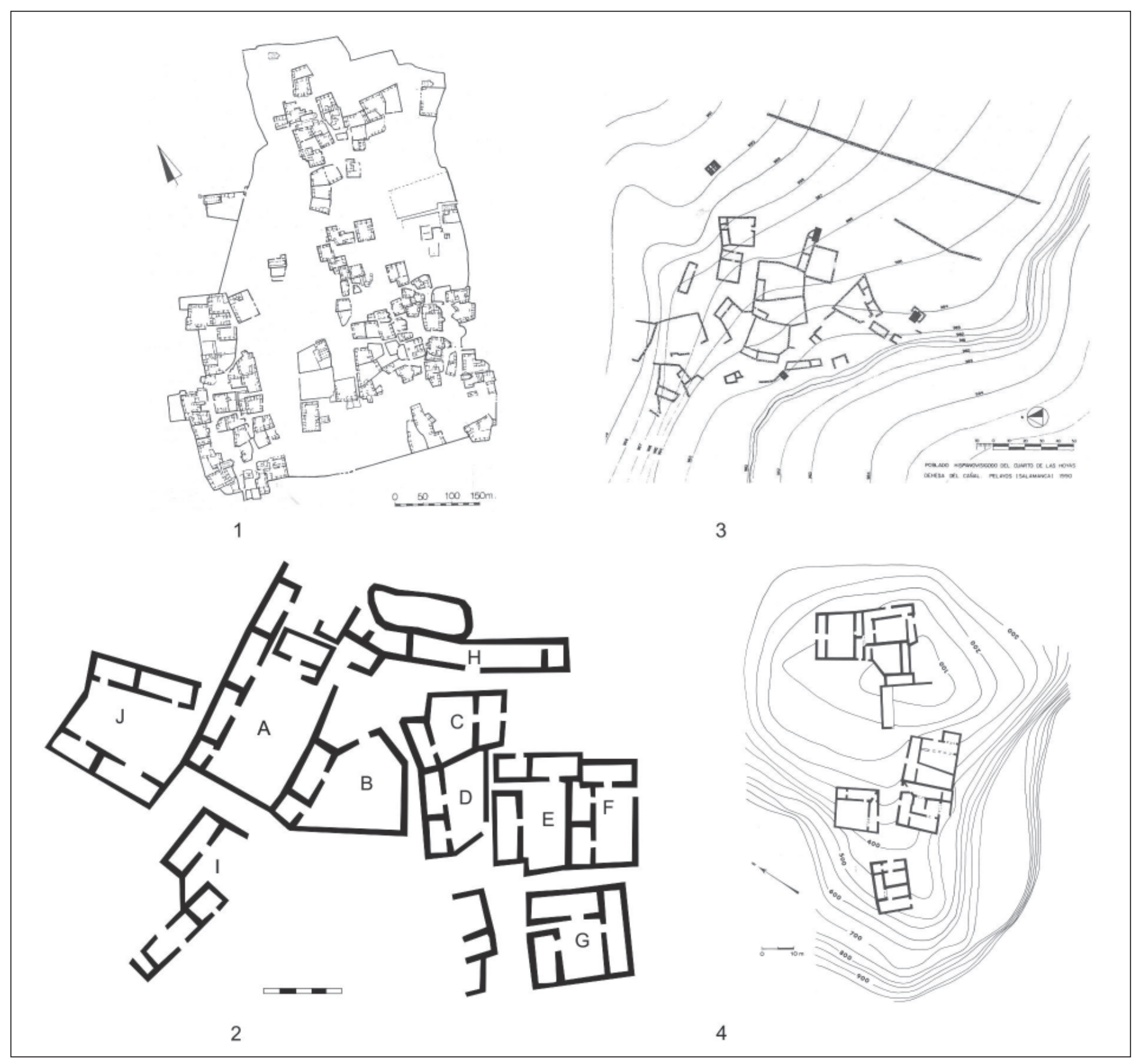

Fig. 8. Unidades domésticas colindantes agrupadas: 1. Umm al-Jimal, Siria, ss. v-VII (según Vries apud Fentress 2000: fig 9; Vries 2000: fig. 2); 2. Cuarto de las Hoyas, El Cañal de Pelayos, Salamanca, s. VII (según Storch de Gracia 1998); 3. Peñaflor, s. Ix (según Salvatierra Cuenca et alii 2000: fig. 12) y 4. L’Adsubieta, Vall d'Alcalá, Alicante, ss. XIV-XVII (según Bazzana 1992, II: fig. 271, a partir de Torró e Ivars 1990: fig. 8)

\subsubsection{Organización alineada}

Las unidades domésticas con una organización alineada son aquellas que se disponen, sea cual sea su patrón, en una secuencia lineal o serie de espacios repetidos (Ching 2006: 189), de forma que comparten las paredes medianeras entre sí. Esta disposición, muy típica de los asentamientos concentrados protohistóricos, se documenta generalmente en asentamientos rurales medievales, tanto de época visigoda como en Vilaclara, Castellfollit del Boix en
Barcelona (Fig. 9, 2.1), donde se disponen entre tres y cuatro unidades domésticas formadas por uno o dos módulos con su patio frontero y al menos un espacio común donde se ubica el horno, como de época islámica en el caso de la alquería de Foietes d'alt, L'Almisserà en Villajoyosa (Alicante. Fig. 9, 2.2). En este último asentamiento rural del siglo XI se yuxtaponen, adaptándose a la topografía, nueve unidades residenciales complejas o «casas de patio" islámicas de morfología similar a las 


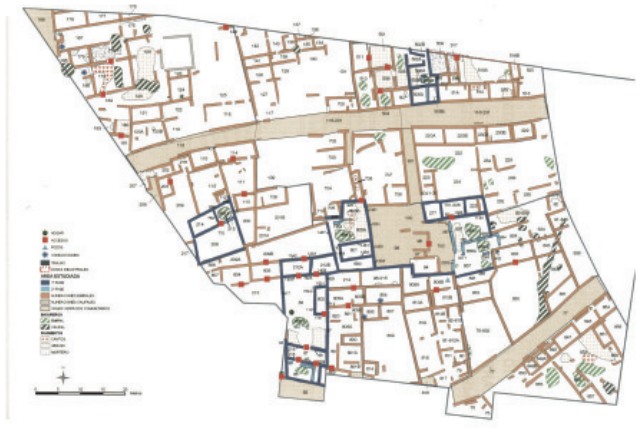

1

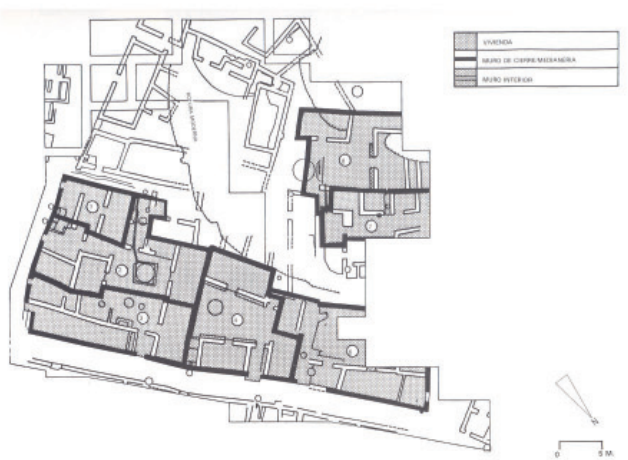

2

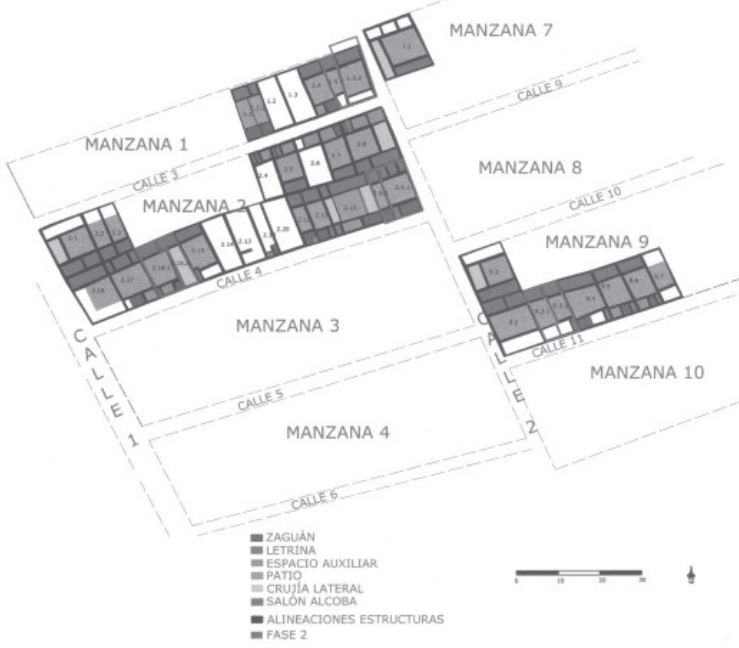

3

1
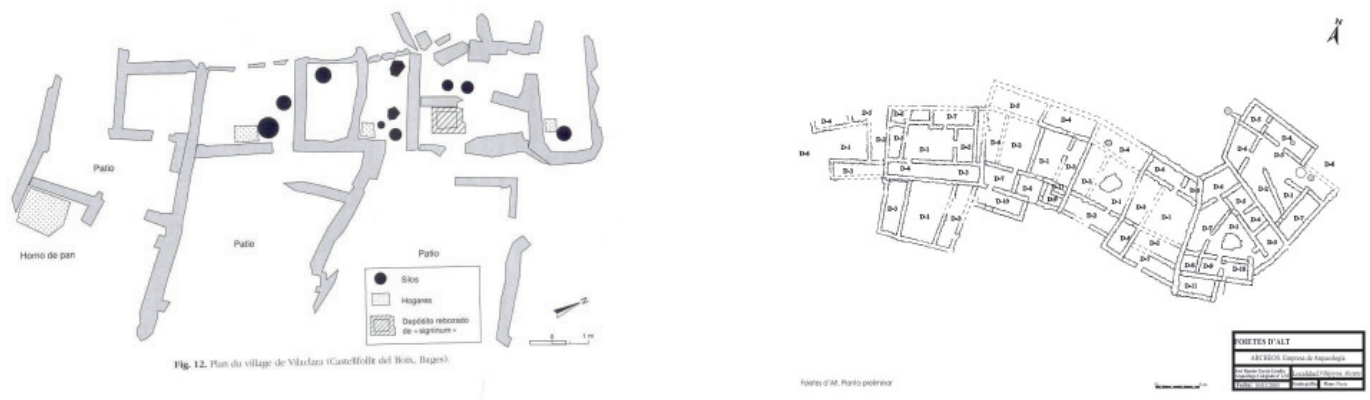

1

2

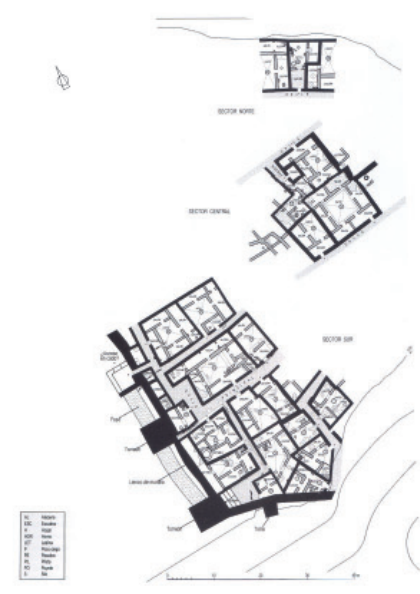

4 
urbanas, ilustrando un contexto de islamización social del medio rural.

\subsubsection{Organización en trama}

La organización en trama supone la disposición de las unidades domésticas en el interior de un tejido urbano coherente, estructurado y compacto, que define ejes de circulación entre las formas construidas (Ching 2006: 189). Es la forma de organización característica de la mayoría de asentamientos concentrados, tanto urbanos como rurales y puede adaptarse a esquemas regulares e irregulares. Aunque tradicionalmente se presuponía que las organizaciones urbanas medievales y en especial las islámicas raramente eran orgánicas y regulares, caracterizándose por el desorden, la Arqueología ha puesto en evidencia que en cronologías tempranas, tanto en al-Andalus como en Oriente, las tramas regulares e incluso ortogonales son frecuentes (Acién 2001:15). Todos los ejemplos de organización en trama elegidos muestran una distribución compacta, densa y organizada en manzanas, que surgen de la agrupación de varias unidades domesticas colindantes confinadas por los ejes de circulación. Estos últimos se jerarquizan simbólica y materialmente según predomine su carácter vial (destinados a facilitar la comunicación entre diversos sectores del tejido urbano) o residencial (destinados a facilitar el acceso a las unidades domésticas que quedan confinadas en el interior de la manzana).

La precisa cronología del arrabal cordobés de Šaqunda (Fig. 9,1.1) permite reconocer grandes ejes viarios que mantienen su trazado prístino, junto con adarves y plazoletas que dan servicio a las diversas unidades domésticas, y lo que es más significativo definen desde el primer momento de construcción del arrabal a mediados del siglo VIII, los perímetros de las amplias manzanas, no totalmente urbanizadas por la corta vida del arrabal. Las unidades domésticas y productivas, propias de un sector urbano eminentemente artesanal, se organizan en base de cuerpos edificados y amplísimos espacios descubiertos, en un tejido difícil de interpretar, pero con claros indicios de planificación (Casal 2008: 133).

Tanto en Šaqunda como en la ciudad de Baŷȳannal Pechina (primera mitad del siglo X; Fig. 9, 1.2) o en el despoblado de Villa Vieja en Calasparra ( siglo XIII; Fig. 9, 1.4), las unidades domésticas se engarzan unas con otras, definiendo parcelas de contornos irregulares que a menudo se intrusan en las viviendas limítrofes; este rasgo, muy notorio en el parcelario baŷŷāní, ejemplifica el carácter introvertido de la vivienda y quizá el predominio de iniciativas colectivas de planificación basadas en acuerdos vecinales (Acién 2001: 28; Van Staëvel 2004: 38). Por el contrario, el sector occidental del arrabal cordobés de alRus āfa (Fig. 9, 1.3) muestra un trazado ortogonal, con un entramado jerarquizado de vías (las amplias longitudinales, pensadas para la circulación, y las transversales más estrechas a las que se abren las puertas de las unidades domésticas), un sistema organizado de evacuación de aguas residuales y un parcelario regular en forma y tamaño, que define una doble hilera de viviendas rectangulares pareadas y yuxtapuestas, compartiendo medianerías (Murillo et alii 2010: 603-4). La disposición regular de las parcelas prácticamente lotificadas, indica una ocupación organizada y densa, confirmada por la partición longitudinal de ciertas viviendas en una segunda fase de uso. La magnitud de esta planificación urbanística, que no solo implica a este sector del arrabal occidental de al-Rus âfa, fechado en las últimas décadas del siglo $\mathrm{x}$ y los primeros años del XI, sino a todo el espectacular ensanche de Córdoba hacia Madinnat al-Zahrä durante el Califato, permite confrontar la génesis de este proceso con otros modelos de urbanización espontánea más temprana, como el de la propia Pechina.

En este sentido, para el caso cordobés se sugirió un primer impulso urbanístico del siglo IX, en el que la intervención oficial fue difusa y simbólica (fundación de mezquitas y baños) y donde debieron jugar un papel fundamental las formas colectivas de organización vecinal (Acién y Vallejo 1998: 121-2 y Acién 2001: 28), frente a un momento más avanzado en el que la magnitud, coherencia y complejidad urbanística del ensanche occidental parecía sugerir una intervención planificadora del Estado (Acién y Vallejo 1989:133). No obstante sigue siendo difícil calibrar su intervención, no tanto en lo relativo a la planificación de las infraestructuras (parcelación, trazado de vías y saneamientos, patrocinio de edificios públicos, etc.) cuanto en la regulación de los mecanismos de apropiación del suelo edificable, y que en ningún caso está reñida con la aplicación de un conjunto de normas reguladoras centradas en las relaciones de vecindad inmediata (Van Staëvel 2004: 32-34) ${ }^{47}$.

\section{Discusión: formas y relaciones, tiempos y espacios}

La sintaxis de los espacios domésticos medievales refleja distintos patrones de organización y relación de las formas construidas, pero estos no son fijos ni están cronológicamente determinados. Podemos, no obstante, intuir aparentes concomitancias entre los patrones morfológicos de

\footnotetext{
${ }^{47}$ Ejemplos de planeamientos urbanos precisos se aprecian en diversos barrios urbanos, como se ha podido constatar recientemente en el arrabal de Praça da Figueira, en Lisboa (Banha et alii 2011:23 y figs. 3 y 6).
} 


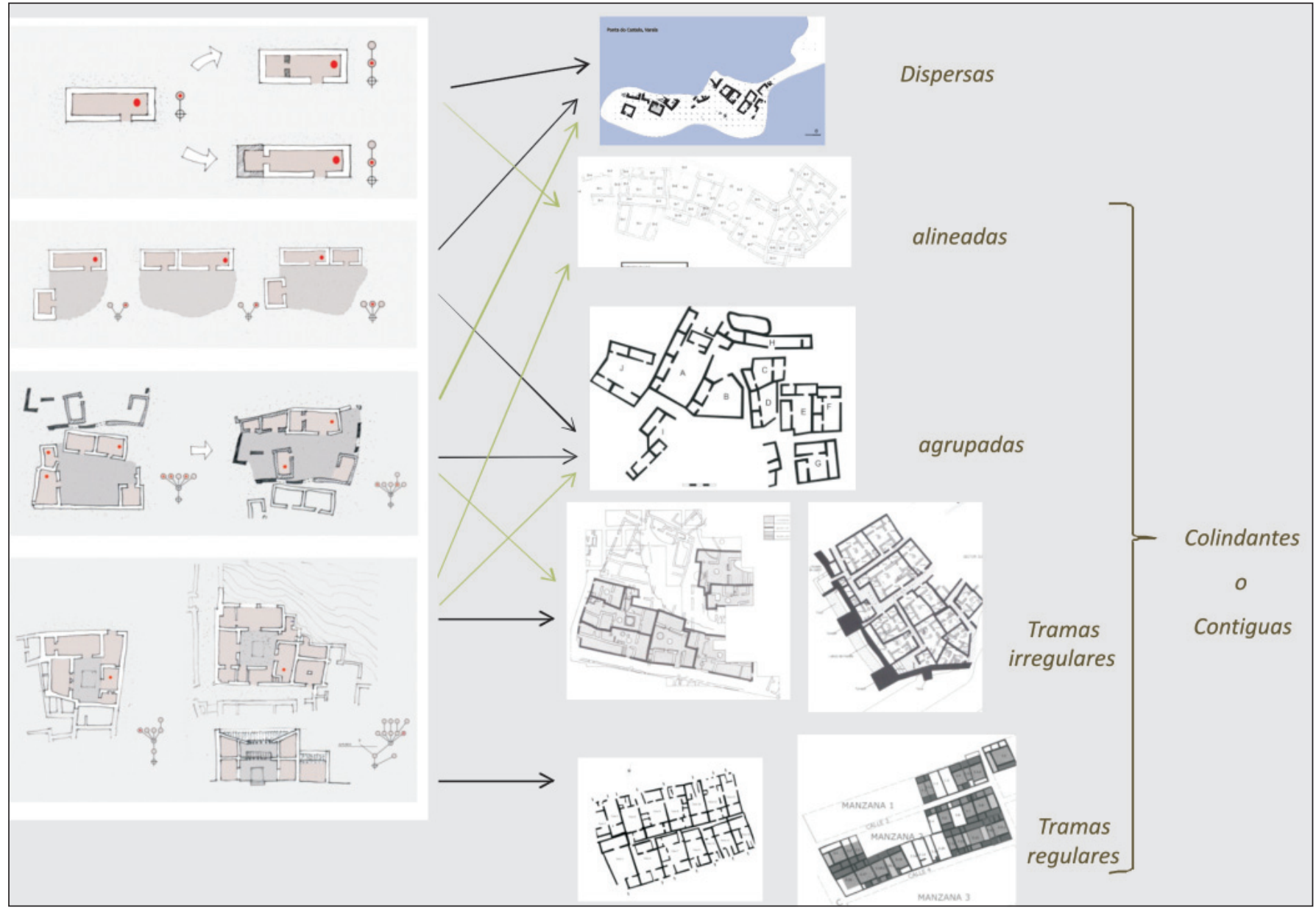

Fig. 10. La sintaxis: formas de agrupación de las unidades domésticas en tramas

unidades domésticas y sus formas de agrupación, que hemos intentado ejemplificar en la figura 10 .

Así, los módulos unicelulares suelen disponerse de forma dispersa y en menor medida en contextos medievales de forma alineada; esta disposición será, por el contrario, frecuente en unidades domésticas protohistóricas caracterizadas por formas de vida expuestas (puerta y hogar en disposición axial), donde los módulos se yuxtaponen a lo largo de un eje o adosados a una cerca defensiva, compartiendo las medianerías más largas (Belarte 2009). En el caso de las estructuras domésticas medievales, la marcada preferencia por los accesos oblicuos en el frontal más largo, condiciona la yuxtaposición a los testeros más cortos, resultando poco frecuente su alineación.

Los módulos asociados pueden disponerse de variadas formas, con cierta preferencia por organizaciones espaciales dispersas o agrupadas, colindando parcialmente. Esta es una forma de disposición muy característica de los asentamientos rurales en diversas cronologías y variados contextos sociales.
Los módulos agregados delimitando un espacio común suelen asociarse en formas agrupadas, esto es colindando parcialmente, o totalmente dispersas, siendo muy frecuente la combinación de ambos sistemas, como se aprecia por ejemplo en la alquería morisca de L'Adsubieta (Fig. 8, 4), aunque también pueden conformar tramas urbanizadas irregulares como se atestigua en el caso de El Tolmo de Minateda (Fig. 4).

Por fin, las unidades modulares complejas estructuradas en torno a un patio, características de sociedades plenamente islamizadas, suelen organizarse en tramas regulares o irregulares, tanto en asentamientos urbanos como rurales. Sin embargo, este patrón también puede aparecer alineado, como ocurre en la alquería de Foietes d'Alt, probablemente por condicionantes topográficos (Fig. 9, 2.2), e incluso, aunque no es muy usual, en forma agrupada como se constata en un contexto rural en la alquería del Tossal de L'Almisserà en Villajojosa, Alicante (García Gandía 2004: 85, fig. 2), en un espacio agrícola de explotación diacrónica donde las zonas de residencia parecen desplazarse entre 
los siglos XI (Foietes d'Alt) y XIII (Tossal de L'Almisserà, entre otras), indicando en ambos casos la profunda imbricación de la "casa de patio" islámica en el medio rural desde el siglo $\mathrm{XI}^{48}$.

La Arqueología pone de manifiesto que las organizaciones domésticas en tramas compactas son características y dominantes en el medio urbano y en ciertos contextos rurales caracterizados por un poblamiento rural concentrado de morfología casi «urbanizada», como es el caso de varias alquerías de época almohade en el sudeste peninsular. Sin embargo, en el medio rural y en asentamientos que no siempre se identifican con zonas de residencia concretas, sino más bien con un espacio agrario, son frecuentes las formas dispersas y diseminadas (Torró 2009: 210) o bien las soluciones agregadas que pueden incluso ir desplazándose por el territorio, manteniendo el anclaje efectivo con los espacios de cultivo (Vigil-Escalera 2009). En cualquier caso la casuística es muy variada y ciertas coyunturas históricas pueden suscitar soluciones imprevistas; es el caso por ejemplo del Castell d'Ambra en Pego, cuya tardía y corta ocupación, casi coetánea a la conquista feudal, y su carácter de refugio de los habitantes de las alquerías circundantes generó morfologías domésticas unicelulares inusuales a mediados del siglo XIII y totalmente distintas a las morfologías coevas de Siyasa o Villavieja, discutidas en este marco (Azuar et alii 1999:293, fig. 2).

\section{UNA REFLEXIÓN ABIERTA: EL CAMINO DE LA SEMIÓTICA}

En origen esta reflexión pretendía organizarse como una gramática de la casa, estructurándose en sus tres dimensiones constitutivas: morfología, sintaxis y semiótica. Los límites impuestos por el marco de este trabajo impiden abordar las relaciones entre los espacios construidos y la estructura social que los concibe y ejecuta a través de expresiones arquitectónicas concretas. Este camino requiere la discusión histórica de algunos problemas que se anuncian: los modelos domésticos medievales como elemento de reconocimiento social, convivencia o hibridación; los marcadores de jerarquización, la ritualización del espacio, la caracterización del poblamiento rural y urbano, la segregación social o sexual de espacios, la definición del hogar, la organización familiar, las diferencias de estatus, etc. Hasta aquí hemos analizado significantes materiales, pero la discusión futura ha de tratar sobre significados sociales y la relación entre ambos está lejos de resultar

${ }^{48} \mathrm{El}$ conjunto agrario de las alquerías de L'Almisserà fue excavado por la Empresa de Arqueología Archeos y en la actualidad se estudia de forma conjunta por un equipo coordinado por José Ramón García Gandía y Sonia Gutiérrez. obvia. Quizá un ejemplo concreto sirva para comprender mejor el problema: los espacios domésticos de Umm alJimal, la ciudad bizantina tempranamente islamizada de Siria, e incluso su forma de organización agrupada (observados necesariamente desde la bidimensionalidad de un plano) son comparables en forma y estructura con los de otros asentamientos altomedievales de la Península Ibérica, ya sean de época visigoda o andalusíes, como el Cuarto de las Hoyas, Peñaflor o el propio Tolmo de Minateda. Basta confrontar su materialidad arquitectónica y productiva para comprender que sus espacios son expresiones sociales difícilmente comparables ${ }^{49}$. En ese nuevo umbral connotado de significados culturales se detiene este trabajo ${ }^{50}$.

\section{Bibliografía}

Abad Castro, C., 2006: «El poblado de Navalvillar», La investigación arqueológica de la época visigoda en la Comunidad de Madrid, Zona Arqueológica 8, II, 388-399.

Acién Almansa, M., 1998: «Sobre el papel de la ideología en la caracterización de las formaciones sociales. La formación social Islámica», Hispania, Vol. LVIII/3, Núm. 200, 915-968.

Acién Almansa, M., 2001: "La formación del tejido urbano en al-Andalus», $L a$ ciudad medieval: de la casa al tejido urbano (J. Passini, coord.), Cuenca, 11-32.

Acién Almansa, M. y Vallejo Triano, A., 1998: «Urbanismo y Estado islámico: de Corduba a Qurțba-Madinat al-Zahrä'», Genèse de la ville islamique en alAndalus et au Maghreb occidental (P. Cressier et M. García-Arenal, eds.), Casa de Velázquez-CSIC, Madrid, 107-136.

Acuto, F. y Zarankin, A. (eds), 2008: Sed non satiata II. Acercamientos sociales en la Arqueología Latinoamericana, Córdoba.

Adánez Pavón, J., 2003: «Una conceptuación de la organización espacial doméstica: morfología y dinámica», Revista Española de Antropología Americana, vol. Extraordinario, 35-53.

Alba, M., 2007: «Diacronía de la vivienda señorial de Emerita (Lusitania, Hispania): desde las Domus altoimperiales y tardoantiguas a las residencias palaciales omeyas (siglos I-IX)", Archeologia e Società tra Tardo Antico e Alto Medioevo, G. P. Brogiolo y A. Chavarria Arnau (cur.), Documenti di Archeologia, 44, 163-192.

Alfaro Arregui, M. y Martí Bañón, A, 2006: «La Vega: un modelo de asentamiento rural visigodo en la provincia de Madrid», La investigación arqueológica de la época visigoda en la Comunidad de Madrid, Zona Arqueológica 8, II, 402-417.

Allison, P.M.( ed.) 1999: The Archaeology of Household Activities, Routledge. London and New York.

Amamra, A.-A. y Fentress, E., 1990: «Sétif: evolution d'un quartier», La casa hispano-musulmana. Aportaciones de la arqueología. La maison hispano-musulmana. Apports de l'Archeologie, Granada, 163-76.

Ayán Vila, X. M. et alii, 2003: Archaeotecture: Archaeology of Architecture, BAR Int. Ser. 1175, Archaeopress, Oxford.de la Arquitectura.

Azkarate Garai-Olaun, A., 2010: "Archeologia dell'Architettura in Spagna», Archeologia dell'Architettura, XV, 2010,15-26.

Azkarate Garai-Olaun, A., (e.p): «La construcción y lo construido. Arqueología de la Arquitectura", La materialidad de la Historia (J. A. Quirós, ed.), Akal, Madrid.

${ }^{49}$ La arquitectura bizantina de Umm el-Jimal utiliza profusamente la sillería en edificios de varios pisos, con soluciones arquitectónicas y decorativas complejas que denotan una significativa especialización en los procesos productivos, mientras los ejemplos hispanos denotan un ambiente técnico muy diferente. Sobre Umm el-Jimal Project ( http://www.ummeljimal.org/).

${ }^{50}$ Vid. Supra n. 10. 
Azkarate Garai-Olaun, A. y Quirós Castillo, J. A., 2001: «Arquitectura doméstica altomedieval en la Península Ibérica. Reflexiones a partir de las excavaciones arqueológicas de la Catedral de Santa María de Vitoria-Gasteiz, País Vasco", Archeologia Medievale, XXVIII, 25-60.

Azkarate Garai-Olaun, A. y Solaun Bustinza, J. L., 2009: «Nacimiento y transformación de un asentamiento altomedieval en un futuro centro de poder: Gasteiz desde fines del siglo VII d.C. a inicios del segundo milenio", The Archaeology of Early Medieval Villages in Europe, (J. A. Quirós, ed) Universidad del País Vasco, Bilbao, 405-428.

Azkarate Garai-Olaun, A. y Solaun Bustinza, J. L. (e.p.): «Tipologías domésticas y técnicas constructivas en la primitiva Gasteiz (País Vasco) durante los siglos VIII al XII d.C.», enviado a Arqueología de Arquitectura.

Azuar, R.; Martí, J. y Pascual, J., 1999: «El Castell d'Ambra (Pego). De las producciones andalusíes a las cerámicas de la conquista feudal (siglo XIII)». Arqueología y Territorio Medieval, 6, Jaén, 279-301.

Baldini Lippolis, I., 2010 : «Edilizia residenziale e società urbana», STAIM 2. Paesaggi e insediamenti urbani in Italia meridionale fra tardoantico e altomedioevo, 45-60.

Banha da Silva, R.; Gomes, R. Varela y Gomes, M. Varela, 2011 : «O Bairro islámico da Praça da figueira (Lisboa)", Cristâos e Muçulmanos na Idade Média Peninsular. Encontros e Desencontros, IAP (Instituto de Arqueología y Paleociências), 17-26.

Bazzana, A. 1992: Maisons d'al-Andalus. Habitat médiéval et structures du peuplement dans l'Espagne orientale, Madrid.

Bazzana, A. 2011 : «Quelques réflexions sur les caractères de l'espace domestique dans al-Andalus, et son évolution des musulmans aux chrétiens", Cristâos e Muçulmanos na Idade Média Peninsular. Encontros e Desencontros, IAP (Instituto de Arqueología y Paleociências), 51-66.

Bazzana, A. y Bedia García, J., 2009: Saltés. Un asentamiento islámico en las Marismas del Odiel (siglos IX-XIII), Huelva Arqueológica, 21, Casa de Velázques-Diputación de Huelva.

Bazzana, A. y Cressier, P., 1989: Shaltîsh/Saltés (Huelva): une ville médiévale d'alAndalus, CCV 25, Madrid.

Belarte Franco, M. C. (ed.), 2009: L'espai domèstic i l'organització de la societat a la protohistòria de la Mediterrània occidental (1er mil.lenni aC). Actes de la IV Reunió Internacional d'Arqueologia de Calafell (Calafell-Tarragona, 2007), Arqueo Mediterrània, 11, Universitat de Barcelona-ICAC.

Belarte Franco, M. C.; Bonet Rosado, H.; Sala Sellés, F., 2009: «L'espai domèstic i l'organització de la societat ibèrica: els territoris de la franja mediterrània», Arqueo Mediterrània, 11, Universitat de Barcelona-ICAC, 93-123.

Bermejo Tirado, J., 2007-2008: «Arqueología de las actividades domésticas: una propuesta metodológica para el mundo romano", La arquitectura doméstica romana en el ámbito urbano y rural, Anales de Prehistoria y Arqueología., vol. 23-24, Universidad de Murcia, 131-151.

Bermejo Tirado, J., 2009: «Leyendo los espacios: una aproximación crítica a la sintaxis espacial como herramienta de análisis arqueológico, Arqueología de la Arquitectura, 6, 47-62.

Boone, J. L., 1996: «Uma sociedade tribal no Baixo Alentejo medieval?», Arqueologia Medieval (Mértola), 4, 25-36.

Boone, J. L., 2001: «Tribalism, Ethnicity, and Islamization in the Baixo Alentejo of Portugal: Preliminary results of investigation into transitional period (AD 550-850) rural settlements», Era-arqueologica, revista de divulgaçao cientifica de estudos arqueologicos, $\mathrm{n}^{\circ}$ 4, dezembro, 104-121.

Bourdieu, P., 1972 : Esquisse d'une Théorie de la Pratique, précédé de trois études d'ethnologie kabyle, Genève.

Bourdieu, P., 1973: «The Berber house», M. Douglas (ed.), Rules and Meanings: An Anthropology of Everyday Knowledge, Harmondsworth, Penguin Education, 98-110.

Bourdieu, P. 2007: Antropología de Argelia. Prólogo, estudio preliminar y revisión de la traducción de Elena Hernández Corrpochano, Editorial Universitaria Ramón Areces, Madrid.

Brett, M. \& Fentress, E. 1996: The Berbers, Blackwell Publishers, Oxford. Brogiolo, G. P., 2011: Le origini della città medievale, Pca 1, Mantova.

Castillo Galdeano, F. y Martínez Madrid, R., 1990: «La vivienda hispanomusulmana en Baŷŷāna", La casa hispanomusulmana. Aportaciones de la Arqueología. La maison hispano-musulmana. Apports de l'Archeologie, Granada, 111-128.
Cánovas Ubera, A.; Castro del Rio, E. y Moreno A., M., 2008: «Análisis de los espacios domésticos en un sector de los arrabales occidentales de Qurțūba», Anejos de Anales de Arqueología Cordobesa, 1, Córdoba, 201-20.

Casal García, T., 2008: «Características generales del urbanismo cordobés de la primera etapa emiral: el arrabal de Šaqunda", Anales de Arqueología Cordobesa, 1, Córdoba, 109-34.

Casal, T.; Martínez, R. y Areque, Ma del M., 2009-2010: «Estudio de los vertederos dométicos del arrabal de Šaqunda: ganadería, alimentación y usos derivados (750-818 d. C.), Anejos de Anales de Arqueología Cordobesa, 2, Córdoba, 143-182.

Chavarria Arnau, A., 2007: El final de las villae en Hispania (SS. IV-VII D. C., Brepols Publisher.

Ching, F. D. R., 1995: Arquitectura: forma, espacio y orden, México, Gustavo Gili.

Cressier, P. y Gutiérrez Lloret, S., 2009 : «Archeologie de l'Islam européen: sept siècles de présence arabo-berbère», L'Europe: un continent redécouvert par l'archéologie, Jean-Paul Demoule (dir.), Paris, Gallimard, pp. 149-157.

Criado Boado, F. 1999: Del terreno al espacio: planteamientos y Perspectivas para la Arqueología del Paisaje, CAPA, nº 6, Santiago.

Criado, F.; Mañana, P., 2003: "Arquitectura como materialización de un concepto. La espacialidad Megalítica». Arqueología de la Arquitectura, 2, 103111.

Criado Boado, F., 2012: Arqueológicas. La razón perdida, Bellaterra-arqueología, Barcelona.

Cribb, R. L. D. 1991: «Mobile villagers: The structure and organisation of nomadic pastoral campsites in the Near East», Ethnoarchaeological Approaches to Mobile Campsites: Hunter Gatherer and Pastoralist Case Studies, 371-393.

Cribb, R., 1991: Nomads in Archaeology, Cambridge University Press, Cambridge.

Corriente, F., 2003: Diccionario de arabismos y voces afines en iberorromance, Gredos, 2a ed. Ampliada, Madrid.

Eco, U., 1986: La estructura ausente. Introducción a la semiótica, Lumen, Barcelona.

Enrich, J.; Enrich, J. y Pedraza, LL., 1995: Vilaclara de Castellfollit del Boix (el Bages), Barcelona.

Fantar, M., 1985: Kerkouane. Cité punique du Cap Bon (Tunisie), T. II, Architecture doméstique, Túnez.

Fentress, E., 1987: «The house of the prophet: North African Islamic Housing», Archeologia Medievale, 14, 47-68.

Fentress, E., 2000: «Social relations and Domestic space in the Maghreb», Castrum 6. Maisons et espaces domestiques dans le Monde Méditerranéen au Moyen Âge, CEFR-105/6 y CCV 72, Rome-Madrid, 15-26.

Fentress, E. \& Limane, H., 2010: «Excavations in Medieval settlements at Volubilis. 2000-2004", Cuadernos de Madinnat al-Zahrä, 7, 105-122.

Fernández Souza, L., 2010: Grupos domésticos y espacios habitacionales en las Tierras Bajas mayas durante el periodo Clásico, (Dissertation zur Erlangung der Würde des Doktors der Philosophie), Hamburg (http://ediss.sub.unihamburg.de/volltexte/2010/4512/pdf/Dissertation.pdf).

Funari, P. P. y Zarankín, A., 2001: «Algunas consideraciones arqueológicas sobre la vivienda doméstica en Pompeya», Gerión, 2001, no 19, 493-511.

García, D., 2009: «L'organisation sociale des communautés du premier âge du Fer en Celtique méditerranéenne: ce que pourraient nous révéler les données de l'habitat...", Arqueo Mediterrània, 11, Universitat de Barcelona-ICAC, 5765.

García Gandía, J.R.; Llorens Campello, S. y Pérez Botí, G., 2004: «L'Almisserà: territorio castral y espacio rural en época islámica», De la Medina a la Vila, Alicante, 83-105.

Gomes, R. V., 2011: «El mundo rural en el sur del actual territorio portugués (siglos XII-XIII)», Arqueología Medieval. Els espais de secà, IV/ 2010, Pagès editors, Lleida, 99-116.

Grau Mira, I., (e.p.), «Unidad doméstica, linaje y comunidad: estructura social y su espacio en el mundo ibérico", International Workshop From domestic structure to social life. Archaeological readings of social use of space (Alicante, mayo, 2012).

Guichard, P. et Van Staëvel, J.-P, 1995: «La casa andalusí: ensayo de lectura antropológica»», Casas y palacios de al-Andalus, Granada, 45-51. 
Gurt Esparraguera, J. M. y Palet Martínez, J. M., 2001: «Structuration du territoire dans le Nord-Est de l'Hispanie pendant l'Antiquité tardive transformation du paysage et dynamique du peuplement», P. Ouzoulias, C. Pellecuer, C. Raynaud, P. Van Ossel, P. Garmy (dirs.), Les campagnes d ela Gaule à la fin de l'Antiquité. Habitat et peuplement aux Ive et Ve siècles. Colloque AGER IV. Editions APDCA, Antibes, 2001, p. 303-329.

Gutiérrez Lloret, S., 1999: «La cerámica emiral de Madīnat Iyih (el Tolmo de Minateda, Hellín, Albacete). Una primera aproximación». Arqueología y Territorio Medieval, 6, Jaén, 71-111.

Gutiérrez Lloret, S., 2008: "Madīnat Iyyuh y la destrucción del espacio urbano en la Alta Edad Media", Castrum 8. Le château et la ville. Espaces et réseaux (VIe-XIII siècle). Espacios y redes. SS. VI-XIII, Cressier, P. (ed), Collection de la Casa de Velázquez (108), Madrid, 199-222.

Gutiérrez Lloret, S. 2011: «La arqueología en la historia del temprano alAndalus: espacios sociales, cerámica e islamización», Ph. Sénac (ed) Histoire et Archéologie de l'Occident musulman (VII e-Xve siècle): Al-Andalus, Maghreb, Sicile. Villa 4, Études Médiévales Ibériques, Méridiennes, 33-66.

Gutiérrez Lloret, S. (e.p.), «Formas de habitar en el temprano al-Andalus Significado social del espacio doméstico", International Workshop From domestic structure to social life. Archaeological readings of social use of space (Alicante, mayo, 2012).

Gutiérrez Lloret, S. y Cánovas Guillén, P., 2009: «Construyendo el siglo VII: arquitecturas y sistemas constructivos en el Tolmo de Minateda», El siglo VII frente al siglo VII. Arquitectura, Anejos de AEspA XLVIII, 91-131.

Gutiérrez Lloret, S. y Cañavate Castejón, V., 2010: «Casas y cosas: espacios y funcionalidad en las viviendas emirales del Tolmo de Minateda (Hellín, Albacete)», Cuadernos de Madinat al-Zahrä, 7, 123-148.

Hamerow, H., 2007: Early Medieval Settlements. The Archaeology of Rural Communities in Northwest Europe 400-900, Oxford University Press, reprinted (1t ed. 2002).

Hillier, W. y Hanson, J., 1984: The social logic of space, Cambridge.

Jiménez Castillo, P. y Navarro Palazón, J. 1997: Platería 14. Sobre cuatro casas andalusies y su evolución (siglos X-XIII), Serie Excavaciones arqueológicas en la Ciudad de Murcia, 1, Ayuntamiento de Murcia.

Kent, S. (ed.), 1990: Domestic Architecture and the Use of Space: An Interdisciplinary Cross-Cultural Study, Cambridge University Press, Cambridge.

Kiss, D. (e.p.): «Una visión del espacio desde la arquitectura: tres formas de comprender las dimensiones de espacio doméstico", International Workshop From domestic structure to social life. Archaeological readings of social use of space (Alicante, mayo, 2012).

Lavan, L.; Özgemel, L. \& Sarantis, A. (eds.), 2007: Housing in Late Antiquity. From Palaces to Shops, Brill, Leiden- Boston.

Lorrio Alvarado y Sánchez de Prado, Mª. D., 2008: «El Molón (Camporrobles, Valencia): un poblado de primera época islámica», Lucentum. XXVII, 141164.

Lorrio Alvarado, A.; Almagro-gorbea, M.; Sánchez de Prado, Ma. D., 2009: El Molón (Camporrobles, Valencia). Oppidum prerromano y hisn islámico. Guia turistica y arqueológica, Camporrobles.

Macias, S., 2006: Mértola. Le dernier port de la Méditerranée, 3 vols., Campo arqueológico de Mértola, Mértola.

Manzanilla, L. (ed.) 1986, Unidades habitacionales mesoamericanas y sus áreas de actividad, UNAM. México.

Mañana Borrazas, P.; Blanco Rotea, R. y Ayán Vila, X. M., 2002: Arqueotectura I: bases teórico-metodológicas para una Arqueología de la Arquitectura, TAPA. Traballos de Arqueoloxia e Patrimonio, 25, Laboratorio de Patrimonio, Paleoambiente e Paisaxe, Santiago de Compostela.

Miller Lane, B. (ed.), 2007: Housing and Dwelling. Perspectives on Modern Domestic Architecture, Routledge. London and New York.

Missoum, S., 1995: «Una maison berbère au villaje de Aït-Lahcen (Algérie) «, A. Bazzana et M.-C. Delaigue (eds), Ethno-Archéologie Méditerranéenne, Casa de Velázquez, Madrid, 121-134.

Missoum, S., 2010: «La vivienda tradicional en la Cuenca del Mediterráneo: del iwām al Qbū, pasando por el Bahw», Cuadernos de Madinat al-Zahrä, 7, $149-173$.

Murillo, J. F.; Castillo, F.; Castro, E.; Casal, Ma T. y Dortez, T., 2010: «Los arrabales del sector septentrional del Yanib al-Garbi», El anfiteatro romano de
Córdoba y su entorno urbano. Análisis arqueológico (ss. I.XIII d. C.), D.Vaquerizo y J. F. Murillo (eds.), Monografías de arqueología cordobesa, 19, II, 565-615.

Navarro Palazón, J., 1990: «La casa andalusí en Siyâsa: ensayo para una clasificación tipológica", La casa hispano-musulmana. Aportaciones de la arqueología. La maison hispano-musulmana. Apports de l'Archeologie, Granada, 177-98.

Navarro Palazón, J., 1991: Una casa islámica en Murcia. Estudio de su ajuar (siglo XIII), Serie Islam y Arqueología, 1, Ayuntamiento de Murcia.

Navarro Palazón, J. (ed.), 1995: Casas y palacios de al-Andalus. Siglos XII-XIIII, Granada.

Navarro Palazón, J. y Jiménez Castillo, P., 1996: «Plantas altas en edificios andalusíes. La aportación de la arqueología”, Arqueologia Medieval (Mértola), 4, 107-137.

Navarro Palazón, J. y Jiménez Castillo, P., 2007: Siyâsa. Estudio arqueológico del despoblado andalusí (SS. XI-XIIII), El legado andalusí, Murcia).

Navarro Palazón, J. y Jiménez Castillo, P., 2011: «La parición como síntoma de saturación en la ciudad andalusí: los ejemplos de Siyasa y Murcia», Cristâos e Muçulmanos na Idade Média Peninsular. Encontros e Desencontros, IAP (Instituto de Arqueología y Paleociências), 79-94.

Netting, R., Wilk, R., R. y Arnould, E. J. (eds.), 1984: Households: Comparative and Historical Studies of the Domestic Group, Berkeley.

Nevett, L. 1999: House and Society in the Ancient Greek World, Cambridge.

Olmo Enciso, L., 2011: «De Celtiberia a Santabariyya: la gestación del espacio y el proceso de formación de la sociedad andalusí (ss. VIII-IX)», 711. Arqueologia e Historia entre dos mundos, Zona arqueológica, 15, vol. II, 37-62.

Passini, J., 2004: Casas y casas principales urbanas. El espacio doméstico en Toledo a fines de la Edad Media, UCLM, Toledo.

Pozo Martínez. I.; Robles Fernández, A. y Navarro Santa-Cruz, Elvira, 2002: «El despoblado andalusí de Villa Vieja (hisn Qalashbārra). La transformación de una alquería en un hisn de la Cora de Tudmîr», Urbanismo islámico en el sur peninsular y norte de Africa. Actas del Seminario Urbanismo Islámico. Enfoques diversos para una herencia común, Comunidad Autónoma de la Región de Murcia, Murcia, 145-196.

Pérez Ordoñez, A., 2008: «Arquitectura doméstica tardoandalusí y morisca: aproximación al modelo de familia y a su plasmación en la arquitectura y el urbanismo de los siglos XIII al XVI», JAI 2008 (I Jornadas de Jóvenes en Investigación Arqueológica: dialogando con la Cultura Material. UCM, 3-5 de septiembre de 2008), 381-88.

Quirós Castillo, J. A., (ed.) 2009: The Archaeology of Early Medieval Villages in Europe, Universidad del País Vasco, Bilbao.

Steadman S. R., 1996: «Recent research in the archaeology of architecture: Beyond the foundations", Journal of Archaeological Research, 4, 1, 51-93.

Rapoport, A. 1972: Vivienda y cultura, Ed. Gustavo Gili, Barcelona (House Form and Culture, 1969, Englewood cliffs).

Rapoport, A. 1978: Aspectos humanos de la forma urbana. Ed. Gustavo Gili, Barcelona.

Sala Sellés, F. y Abad Casal, L., 2006: «Arquitectura monumental y arquitectura doméstica en la Contestania», Lucentum, XXV, 23-46.

Salvatierra Cuenca, V. y Castillo Armenteros, J. C., 2000: Los asentamientos emirales de Peñaflor y Miguelico. El poblamiento hispano-musulmán de Andalucía oriental. La Campiña de Jaén (1987-1992), Jaén.

Santangeli Valenzani, R., 2011: Edilizia residenziale in Italia nell'altomedioevo, Carocci editore, Roma.

Storch de Gracia y Asensio, J. J., 1998: «Avance de las primeras actividades arqueológicas en los poblados hispanovisigodos de la Dehesa del Cañal (Pelayos, Salamanca)", Arqueología, Paleontología y etnografia (Jornadas Internacionales "Los visigodos y su mundo»), 4, 141-60, Madrid.

Taboada, C. y Angiorama, C.I., 2003: «Buscando los indicadores arqueológicos de la unidad doméstica». Cuadernos de la Facultad de Humanidades y Ciencias Sociales, no 20, noviembre, 393-407. Universidad de Jujuy, versión On-line ISSN 1668-8104.

Teichner, F. y Schierl, M.A., 2006: «Cerro da Vila (Algarve, Portugal). Aldeia do Mar na época islámica", en Al-Ândalus. Espaço de mudanza. Balanço de 25 anos de història e arqueologia medievais. "Seminario Internacional Homenagem a Juan Zozaya Stabel-Hansen» (Mértola, 2005), Mértola, 2006, 123-139. 
Torró Abad, J., 1992: La formació d'un espai feudal. Alcoi de 1245 a 1305, Diputació de València.

Torró Abad, J., 2009: «Formas de poblamiento y urbanismo. Cómo se organizaron los lugares de habitación de los musulmanes del Reino de Valencia (siglos XIII-XVI)", Entre tierra y fe. Los musulmanes en el reino cristiano de Valencia (1238-1609), Universitat de València, 201-217.

Torró, J. e Ivars, J., 1990: «La vivienda rural mudéjar y morisca en el sur del País Valenciano", La casa hispano-musulmana. Aportaciones de la Arqueología, Patronato de la Alhambra y el Generalife, Granada73-99.

Van Staëvel, J.-P, 1995: «Casa, calle y vecindad en la documentación jurídica», Casas y palacios de al-Andalus, Granada, 53-61.

Van Staëvel, J.-P, 2004: «Prévoir, juguler, bâtir: droit de la construction et institutions judiciaires à Cordoue durant le 4e/Xe siècle», Cuadernos de Madinat al-Zahrä, 5, 31-51.

Vaquer, J. M., 2007: «De vuelta a la casa. Algunas consideraciones sobre el espacio domestico desde la arqueología de la práctica», en Procesos Sociales Prehispánicos en el sur Andino: perspectivas desde la casa, la comunidad y el territorio. Axel E. Nielsen, M. Clara Rivolta, Verónica Seldes, María Magdalena Vázquez y Pablo H. Mercolli (eds.), Editorial Brujas. Córdoba. Págs. 1137.

Vigil-Escalera Guirado, A., 2000: «Cabañas de época visigoda: evidencias arqueológicas del sur de Madrid. Tipología, elementos de datación y discusión", Archivo Español de Arqueología, LXXIII, 223-52.

Vigil-Escalera Guirado, A., 2003: «Arquitectura de tierra, piedra y madera en
Madrid (ss. V-IX d. C.). Variables materiales, consideraciones sociales», Arqueología de la Arquitectura, 2, 287-91.

Vigil-Escalera Guirado, A., 2006 a: El modelo de poblamiento rural en la Meseta y algunas cuestiones de visibilidad arqueológica», Gallia e Hispania en el contexto de la presencia 'germánica' (ss. V-VII), BAR IS 1534, 89-108.

Vigil-Escalera Guirado, A. 2006 b: «Primeros pasos hacia el análisis de la organización interna de los asentamientos rurales de época visigoda», $L a$ investigación arqueológica de la época visigoda en la Comunidad de Madrid, Zona Arqueológica 8, II, 366-373.

Vigil-Escalera Guirado, A., 2009: «Las aldeas altomedievales madrileñas y su proceso formativo", The Archaeology of Early Medieval Villages in Europe, (J. A. Quirós, ed) Universidad del País Vasco, Bilbao, 315-339.

Vries, B. de, 2000: "Continuity and change in the urban character of the southern hauran from the 5 th to the 9th century: the archaeological evidence at Umm al-Jimal», Mediterranean Archaeology, Vol. 13, 39-45.

Walmsley, A., 2007: Early Islamic Syria. An archaeological assessment, Duckworth Debates in Archaeology, London.

Wilk, R. y Ashmore, W., 1988: Household and community in the mesoamerican past. University of New Mexico Press. Albuquerque.

Winter, M., 1986: «Unidades Habitacionales Prehispánicas de Oaxaca», Unidades Habitacionales Mesoamericanas y sus Áreas de Actividad (L. Manzanilla, ed.), UNAM. México, 325-374.

Zarankin, A. y Acuto, F. (eds), 1999: Sed non satiata. Teoría Social en la Arqueología Latinoamericana Contemporánea, Buenos Aires.

Recibido: 3 de julio de 2012 Aceptado: 24 de octubre de 2012 